NBER WORKING PAPER SERIES

\title{
IS PAPER MONEY JUST PAPER MONEY? EXPERIMENTATION AND VARIATION IN THE PAPER MONIES ISSUED BY THE AMERICAN COLONIES FROM 1690 TO 1775
}

\author{
Farley Grubb \\ Working Paper 17997 \\ http://www.nber.org/papers/w17997
NATIONAL BUREAU OF ECONOMIC RESEARCH
1050 Massachusetts Avenue
Cambridge, MA 02138
April 2012

Previously circulated as 'Is Paper Money Just Paper Money? Experimentation and Local Variation in the Fiat Paper Monies Issued by the Colonial Governments of British North America, 1690-1775: Part I." A preliminary version of this paper was presented at the Conference on "De-Teleologising History of Money and Its Theory," Japan Society for the Promotion of Science Research-Project 22330102, University of Tokyo, 14-16 February 2012. The author thanks the participants of this conference and Akinobu Kuroda for helpful comments. Tracy McQueen provided editorial assistance. The views expressed herein are those of the author and do not necessarily reflect the views of the National Bureau of Economic Research.

NBER working papers are circulated for discussion and comment purposes. They have not been peerreviewed or been subject to the review by the NBER Board of Directors that accompanies official NBER publications.

(C) 2012 by Farley Grubb. All rights reserved. Short sections of text, not to exceed two paragraphs, may be quoted without explicit permission provided that full credit, including $\odot$ notice, is given to the source. 
Is Paper Money Just Paper Money? Experimentation and Variation in the Paper Monies Issued by the American Colonies from 1690 to 1775

Farley Grubb

NBER Working Paper No. 17997

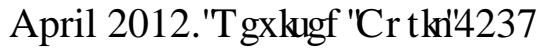

JEL No. E42,E50,F31,G10,H60,K29,N11,N21,N41

\begin{abstract}
The British North American colonies were the first western economies to rely on legislature-issued paper monies as an important internal media of exchange. This system arose piecemeal. In the absence of banks and treasuries that exchanged paper monies at face value for specie monies on demand, colonial governments experimented with other ways to anchor their paper monies to real values in the economy. These mechanisms included tax-redemption, land-backed loans, sinking funds, interest-bearing notes, and legal tender laws. The structure and performance of these mechanisms are explained and assessed. This was monetary experimentation on a grand scale.

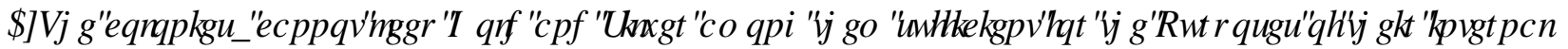

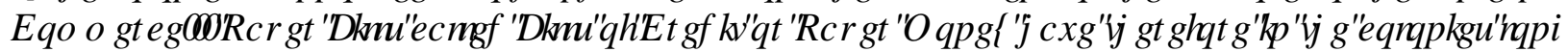
EHQUWXWWXUGFIRULHDOO RQH

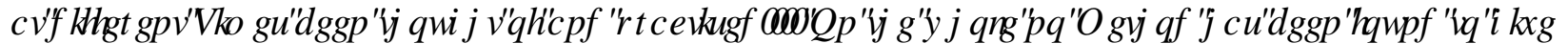

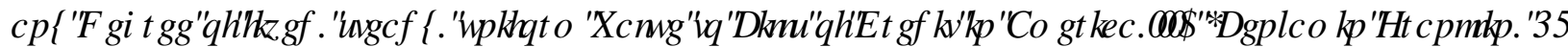
) Hलापिएर
\end{abstract}

Farley Grubb

University of Delaware

Economics Department

Newark, DE 19716

and NBER

grubbf@udel.edu 


\title{
Is Paper Money Just Paper Money? Experimentation and Variation in the Paper Monies Issued by the American Colonies from 1690 to 1775
}

$(4 / 11 / 15)$

\author{
Farley Grubb*
}

The British North American colonies were the first western economies to rely on legislature-issued paper monies as an important internal media of exchange. This system arose piecemeal. In the absence of banks and treasuries that exchanged paper monies at face value for specie monies on demand, colonial governments experimented with other ways to anchor their paper monies to real values in the economy. These mechanisms included tax-redemption, land-backed loans, sinking funds, interest-bearing notes, and legal tender laws. The structure and performance of these mechanisms are explained and assessed. This was monetary experimentation on a grand scale.

[The colonies] cannot keep Gold and Silver among them sufficient for the Purposes of their internal Commerce... Paper Bills called Bills of Credit or Paper Money have therefore in the colonies long been substituted for real Money. Various Ways of issuing these and on different Foundations, have at different Times been thought of and practised.... On the whole no Method has been found to give any Degree of fixed, steady, uniform Value to Bills of Credit in America,...

Benjamin Franklin, 13 Feb. $1767^{1}$

The British North American colonies were the first western economies to experiment with sizable emissions of colony-specific paper monies—called bills of credit. ${ }^{2}$ These bills were emitted by their respective colonial legislatures. No banks issuing paper banknotes exchangeable for their face value in specie on demand existed in North America in this era. ${ }^{3}$ These legislatureissued paper monies formed an important part of the circulating medium of exchange in many colonies (Brock 1975, Newman 2008). These colonial paper-money experiments were neither uniform nor coordinated across the colonies. They were instituted piecemeal—at different times with different motivations and goals. Their institutional structures and relative performances varied. While not consciously intended to be so, either by the colonies or the British government, this was monetary experimentation on a grand scale.

Explaining how colonial paper money regimes performed has proven controversial. 
Economists have found that the statistical relationships between the face-value quantities of paper monies in circulation, prices, and exchange rates are weak to non-existent in the colonies south of New England. These findings challenge the applicability of the classical quantity theory of money. Alternative hypotheses to account for these findings have been difficult to empirically test. These hypotheses include possible changes in the non-price components of the equation of exchange and potential currency substitutions between paper and specie monies. When empirical confirmation is lacking, hypotheses proliferate and views calcify. Heated debates over how to characterize colonial monetary behavior are the result. ${ }^{4}$

Economists have typically assumed that colonial paper monies were fiat currencies in fully monetized economies. They have largely ignored the extensive efforts to legislate the structure of money—something easy to ignore if monies are assumed to be fiat currencies. These assumptions and lapses of consideration have permeated past modeling, regardless of monetary ideology. ${ }^{5}$ Poor modeling performance in past studies may be due to the non-applicability of these assumptions and failures to address the structure of money.

This exploratory essay addresses these lapses and assumptions. The experiments in monetary structure engaged in by colonial legislatures are taken seriously—deconstructed, analyzed, and assessed — to see how far such considerations can succeed in yielding a viable alternative understanding of colonial paper money performance. The plea here is to set aside past monetary modeling applications and ideologies, take history seriously, look with fresh eyes, and see if valuable insights can be gleaned from this alternative approach.

The essay proceeds as follows: First, the institutional constraints that circumscribed what the colonies could do money-wise are presented. This analysis establishes why monetary structure matters, and the limiting range of those structures. Second, variations across colonial 
paper money emissions are documented to show that paper monies are not just paper monies. Not only did the structure of paper money differ between colonies, it differed from emission to emission within a given colony. These findings indicate that the face values of paper monies cannot be compared within, or summed across, emissions to measure the amounts in circulation. This observation makes most past studies of colonial monetary performance meaningless—-thus perhaps explaining the poor modeling performance in these studies.

Third, the legal tools colonists had to achieve their monetary goals, through crafting the structure of their paper money, are identified, analyzed, and their potential success assessed. These tools included creating bond-like redemption structures for their paper money, making their paper money a legal tender, and having their paper money pay interest. Redemption entailed removing paper money from circulation, with it being subsequently destroyed, via exchanging it for its face value in specie equivalents at the established redemption date. Redemption mechanisms included accepting paper money in payment of future taxes imposed; emitting paper money through loans to subjects and requiring loan repayments to be in that paper money, or its face value specie equivalents, on a fixed schedule; and creating sinking funds in specie to execute redemption at legislatively determined future dates.

Achieving a sound monetary policy is assumed to be the primary goal influencing how colonial legislatures structured their paper money emissions. A sound monetary policy entailed creating a paper instrument that could serve as an inside money for executing domestic transactions within the colony, with that paper instrument trading at a predictably stable or constant trend value over time relative to its face value in specie. Stable and predictable values reduced the costs of transacting internal trade and so enhanced economic performance. Ideally, those values would always be equal to the paper instrument's specie-equivalent face value. If this 
ideal was not feasible, could the colonists at least produce a paper instrument that would trade at a constant value relative to its specie-equivalent face value? If they could not produce that outcome, could they at least produce a paper instrument with a predictable trend value relative to the paper instrument’s specie-equivalent face value? Assessing how the legal tools at the colonists' disposal worked, and so how successful they were at achieving this monetary goal, is the task of the second half of this essay.

\section{INSTITUTIONAL CONSTRAINTS}

Colonial governments could not create money per se. That was the exclusive prerogative of the sovereign, namely the British Crown. As such, even if the colonies possessed gold and silver bullion—either mined or imported—-they were prohibited from minting their own coins. What colonial governments could do was create tradable debt in the form of bills of credit (Newman 2008, p.10). Most colonial bills were non-interest-bearing.

The argument that colonial paper money was a debt on which no interest should be paid is illustrated in a speech by Jeremiah Bass (1717, p. 19), assemblyman from Salem County, to the New Jersey assembly on 16 January 1717 ,

To lay a Tax to be paid immediately is impractical and impossible. shall we then borrow Money at Interest, and pass an Act for the Re-payment as the Taxes come in? This would be like the Ass laden with Wool, that lay down in the River to alleviate his Burthen. What then remains but that we borrow of our selves without interest? I mean, that we establish a proper credit, strike so many Bills as will pay the Arrearage, and change the outstanding Bills, and provide an Indubitable Fund for the annual sinking of them. Of all Expedients, I am sure, this will be the most sure, facile and acceptable to the Province. It will furnish us with a current Stock of Money for carrying on our Trade, and payment of our Taxes, give the People Time to make the best Market of their Provisions; and that will render the payment of these Debts of the Province less Injurious to the People.

Bass argued that paper money was a debt that had to be repaid and, because it was a borrowing from ourselves, paying interest was unnecessary. Paying interest also produced an unattractive tax burden. Most bills of credit were structured as zero-coupon bonds (Smith 1937, pp. 310-2). 
Oversight by the British government and by the proprietors of some colonies constrained paper money creation. Paper money acts could be disallowed. The debates with a colony's proprietor were often not about paper money per se, but about political rights and prerogatives. Typically, proprietors wanted to be exempt from having to accept their colony's bills in payment of the quit rents owed them, and proprietors also wanted a say in how bills could be spent. Colonial assemblies typically wanted the opposite. Wrangling over these issues often delayed and shaped paper money acts (e.g. see Brock 1975, pp. 354-62; Grubb 2008).

Colonial paper money legislation was also constrained by the British Parliament. In 1741, Parliament extended the 1720 Bubble Act to the colonies. This made joint-stock corporations, except those chartered by the Crown, illegal (Harris 1994; Newell 1998, pp. 228-30; Priest 2001, p. 1379; Smith 1937, p. 304). Thus, banking operations in the colonies were made prohibitively costly in terms of being unable to adequately raise capital and spread risk among bank stockholders. Banking structures successfully emitting paper banknotes backed by fractional specie reserves, with banknote exchangeable for their face value in specie on demand at the issuing bank, would not appear until near the end of the American Revolution. Specie-based fractional-reserve banking was seen as the preferred way to emit a paper instrument that would always, except in liquidity crises, trade at its face value in specie. Colonists understood this, but were effectively barred from this line of monetary development by British regulation. ${ }^{6}$

Problems with New England's paper money led Parliament to pass the Currency Act of 1751 (Newell 1998, pp. 231-33; Officer 2005; Priest 2001, pp. 1383-1384). This Act applied only to New England. It outlawed making bills of credit a legal tender in private transactions. It also restricted the emission-to-final-redemption interval to be a maximum of two years in peacetime and five years during wartime. Problems with Virginia's bills in the early 1760s led 
Parliament to pass the Currency Act of 1764. This Act applied to all the colonies and outlawed making bills of credit a legal tender for any transaction. It did not restrict the emission-to-finalredemption interval as was done to New England by the Currency Act of 1751. After colonial protests, Parliament in 1773 amended the Currency Act of 1764 to allow bills to be made a de jure legal tender for public debts (Ernst 1973, pp. 77-88, 282-311).

The prior literature fails to explain why these Acts took the form they did. The Acts did not prohibit paper money as is often erroneously stated in the literature. Given that legal tender laws did not determine the market value of paper money (established below), why were these Acts primarily about legal tender laws? The analysis here treats bills of credit as zero-coupon bonds and legal tender laws as a tort law problem. This treatment makes consistent and coherent sense of these Acts.

Lastly, the British government did not allow the colonies to implement capital-trade controls that would restrict the exportation of specie monies from the colonies. By contrast, the British government restricted the free exportation of specie monies from Britain. Colonists constantly complained that as fast as specie monies were imported they were exported to England to cover the colonies’ trade deficits with the mother country. The conditions necessary for chronic specie scarcity were present in colonial America (Grubb 2012). Colonial treasuries never held specie reserves in meaningful quantities. Colonial treasuries functioned only as an intermediary between tax inflows and colonial assembly spending outflows.

\section{HOW COLONIAL PAPER MONIES DIFFERED}

Appendix Table A1 documents the individual paper money emissions in British North America by colony in sequence from the first emission through 1774. This information was taken from original legislation, i.e. from primary sources, for New York through Virginia, and 
from secondary sources for New England, North and South Carolina, and Georgia. In addition, information was taken from what was printed on surviving bills as compiled by Newman (2008). While this information is a substantial improvement over the prior literature, information gaps, indicated in the table, still need to be filled by future research.

Paper money emissions began in 1690 in Massachusetts; 1703 in South Carolina; 1709 in Connecticut, New Hampshire, New Jersey, and New York; 1710 in Rhode Island; 1712 in North Carolina; 1723 in Pennsylvania and Delaware; 1733 in Maryland; and 1755 in Virginia and Georgia. Once initiated, colonial legislatures, with irregular frequency, continued to enact new emissions. Appendix Table A1 shows considerable variation in the size, structure, and characteristics of the paper money authorized, both across colonies and over time within a given colony. Some emissions paid an interest, and some did not. Some emissions were made a legal tender, and some were not. Emissions had differing redemption intervals specified in their authorizing legislation. Some emissions had portions set aside as land-backed loans for the colony’s subjects, and some did not. Some emissions had future redemptions linked to an accumulating sinking fund comprised of specie-denominated assets. Most emissions, however, linked future redemptions to explicit taxes or land-backed loans that could be paid in those emissions or their specie equivalents.

Appendix Table A1 shows that most emissions had legislated redemption periods. These periods varied by emission both across colonies and across emissions within a given colony. The typical redemption window had bills removed at a rate of $1 / \mathrm{N}$ per year over an $\mathrm{N}$ year redemption span which typically ran from the year after initial emission to the last year $(\mathrm{N})$ of the legislated redemption window. Different emissions had different N-year spans. Some redemption legislation imposed slight variations on the $1 / \mathrm{N}$ method, with $1 / \mathrm{N}$ not being exactly 
the same in all years or with redemptions not starting until some years after the first bills were emitted. Redemption structures were occasionally altered by legislatures given emergency circumstances or to correct past failures to execute redemptions as legislated. Some emissions, e.g. Maryland, were legislated to be redeemed only in year N.

Because most emissions did not pay interest and had explicitly legislated redemption dates, they can be characterized as zero-coupon bonds with various maturities. Given the variation in maturity dates, the present value of the bills when treated purely as bonds would experience substantial differences both across colonies and across emissions within a given colony. This observation implies that summing the face of value of bills from different emissions, or even the same emission at different points in time, is a meaningless exercise. The present value of a bill was contingent on its uniquely legislated redemption structure, on its timing and location within that redemption structure, and on the discount rate. Paper money was not just paper money.

Interest bearing bills only appear in New England after the passage of the 1751 Currency Act, in Virginia from 1755-6, and in North Carolina from 1756-8. A few colonies had de facto interest payments attached to their first emissions in the form of payment discounts when using their bills, e.g. see Massachusetts, Connecticut, New Hampshire, New York, New Jersey, North Carolina, and South Carolina. After these initial emissions, these colonies turned to a zerocoupon bond structure for subsequent new emissions. Lastly, most colonies made their bills legal tender within their colony until they were stopped by either the 1751 or 1764 Currency Acts. This behavior, however, was not universal. A few emissions in early New Hampshire, Rhode Island, North Carolina, and South Carolina were not designated a legal tender even though doing so would have been allowed. 
Most emissions were injected into the economy via direct spending by the colony's legislature. This direct spending of emissions was concentrated in war periods, i.e. 1690-1 for King William's War, 1702-13 for Queen Anne’s War, 1739-48 for the War of Jenkin’s Ear and King George’s War, and 1754-63 for the Seven Years and French and Indian War. Most of this direct spending was paying war cost, e.g. soldiers' pay and war materials. These direct-spending emissions were also primarily linked to redemption via future tax payment obligations legislated concurrently with the paper money acts.

By contrast, land-bank emissions were more likely to occur during peacetime. When there were not enough spending obligations to support the direct injection of bills into the economy, legislatures needed some other way to injects bills into the economy. Allowing subjects to borrow newly printed bills from the treasury at a below-market interest rate, with the borrower's lands pledged as collateral for the loan, was a popular peacetime bill-injection mechanism. A few other bill-injection mechanisms were used, such as Maryland using some of its first emission to pay planters to destroy trash tobacco in their possession.

Lastly, Appendix Table A1 shows that most emissions of a given colony, given their redemption time windows, overlapped in circulation with the circulation of immediately prior and immediately subsequent emissions. Overlapping emissions are an interesting phenomena that have not been previously addressed in the literature. Their role in stabilizing the value of bills over time is discussed below.

What was printed on the bills provided holders with information about the structure of each emission. Besides the monetary denomination, two additional pieces of information appeared on all bills, namely the date of emission and the colony emitting the bill. Thus, subjects could always distinguish emissions by the colony-date printed on the face of the bill. This 
information could then be matched to the dates of the authorizing legislation, thus providing subjects with complete information about how each emission was structured.

The material printed on the face of the bills also provided consistent information about whether interest would be paid. When a bill paid interest, that fact, along with the interest rate, was always printed on the face of the bill. By inference, when no interest rate was printed on the face of the bill, a subject could be certain that the bill paid no interest. By contrast, the redemption dates for specific emissions were only irregularly printed on the face of the bills. In some colonies, redemption dates were often printed on the face of the bills, e.g. see Connecticut, New Hampshire, Rhode Island, North Carolina, Georgia and, after 1740, South Carolina. In some colonies, no redemption dates were printed on the bills even though redemption dates were so legislated, e.g. see New York, New Jersey, Pennsylvania, Maryland, and Virginia.

Information printed on the bills about what the bill was valued in or its redemption value varied across emissions, both across colonies and over time within a given colony. This information functioned as unit-of-account references for the numerical value printed on the bill. “Lawful money”, “current money”, “proclamation money”, or some specie measurement statement on the face of the bill referred to the unit-of-account equivalence between pounds sterling, or the specie money named, and the pounds of a particular colonies. These equivalences served unit-of-account and tax-receipt purposes only. No one, including colonial treasuries, stood ready, or were obligated, to exchange bills for specie on demand at the unit-of-account equivalences stated on the face of the bills. These unit-of-account equivalences fixed values for redemption purposes only.

Statements printed on some bills indicate how the bills could be redeemed. Early on in New England, New York, and New Jersey a subject could redeem a bill at the treasury of the 
respective colony for any "stock" or "fund" in the treasury. While such statements printed on the bills disappeared by mid-century, this redemption option continued to be legislated into each emission's structure. Colonies employed this option to rebalance paper money redemption requirements within their respective colonies. When a colony emitted paper money, it also set future taxes or loan principal repayments to redeem and remove that paper money from circulation. Colonial assemblies realized that at the point of redemption the future tax and loan payment obligations used to retire the paper money and the possession of that paper money would not be perfectly synchronized among its subjects. The transaction costs of trading paper money among a colony's subjects to perfectly realign each subject's possession of paper money with that subject's tax and loan payment obligations were burdensome and fraught with potential hold-ups and leveraged rent-seeking of one subject against another.

Colonial assemblies solved this problem by allowing subjects to pay their tax and loan payment obligations either in the colony's paper money or in some other medium, such as in grain or specie, at a fixed rate to the colony's paper money. Subjects that did not have, or could not acquire in time, the colony's paper money, paid their taxes and loan payments in these other media. Subjects that had more paper money than they owed in taxes and loan payments could cash-in their excess balances of paper money at the colony's treasury for the grain or specie at the bill's face value equivalent, i.e. for the "stock" or "fund" in the treasury, paid in by the subjects who did not have the paper money to pay their tax and loan payment obligations. Because final paper-money-redemption taxes and loan payments were set equal to the quantity of paper money emitted, this method rebalanced tax and loan payment obligations and paper money holdings among the colony's subject. ${ }^{7}$

Finally, information printed on some bills indicated that future redemption would be in 
sterling bills of exchange. For example, after 1764 Maryland linked redemption of its paper money to a sizable fund it had accumulated in Britain of Bank-of-England stock. Maryland paper bills explicitly stated on their face that the bearer of the bills were entitled to "receive Bills of Exchange Payable in LONDON...” at the rate of four shilling, 6 pence per dollar of the said bill (Newman 2008, pp. 171-3). This entitlement, however, was not for exchange on demand, but only for exchange at legislated maturity dates.

In summary, Appendix Table A1 shows considerable variation among the paper monies emitted across the colonies and within a given colony. Paper money was not just paper money. Monetary experimentation on a grand scale was afoot. The structure and performance of the various mechanisms used by the colonies to anchor their paper monies to real values in their respective economies are addressed next. First, some modeling guidance is presented.

The market exchange value (MEV) of bills of credit can be decomposed into their expected real-asset present value (APV), i.e. their value as just another non-money real barter asset; minus a risk discount (RD) that captures any expected default risk connected with this asset; plus their liquidity premium (LP) that encompasses their “moneyness" value, i.e. their extra value as a transacting medium, see equation (1). ${ }^{8}$ All components in equation (1) are calculated as a percentage of face value to be in a comparable metric. For a pure fiat currency $\mathrm{MEV} \approx \mathrm{LP}$ and its $\mathrm{APV} \approx 0$. For a pure commodity or asset money, produced in an open-access competitive market, arbitrage yields $\mathrm{MEV} \approx \mathrm{APV}$, leaving its $\mathrm{LP} \approx 0$ in long-run equilibrium.

$$
\mathrm{MEV}_{\mathrm{t}}=\mathrm{APV}_{\mathrm{t}}+\left(\mathrm{LP}_{\mathrm{t}}-\mathrm{RD}_{\mathrm{t}}\right)
$$

If $\left(\mathrm{LP}_{\mathrm{t}}-\mathrm{RD}_{\mathrm{t}}\right)$ is assumed to be relatively small, then most of MEV is determined by APV, which in turn is governed by the redemption structure legislated. For New Jersey and post1764 Maryland, $\left(\mathrm{LP}_{\mathrm{t}}-\mathrm{RD}_{\mathrm{t}}\right.$ ) has been shown to be relatively small (Celia and Grubb 2014, Grubb 
2014). LP was not directly controlled by the legislature. It was determined by the next best alternative medium of exchange in the colony. RD was under the control of the legislature. They could keep it near zero by crafting a credible redemption structure and following through on its execution. When colonies did that, it was likely that MEV $\approx \mathrm{APV}$. APV was directly controlled by the legislature. They set the parameters that determined the present value of the bond structure underlying their bills of credit, see equation (2).

(2) $\quad \mathrm{APV}_{\mathrm{t}}=f(r, i, r e d)$

where $r=$ the discount rate, $i=$ the interest rate paid on the bills held, and red = length of redemption or maturity structure, with $\partial \mathrm{APV} / \partial r<0, \partial \mathrm{APV} / \partial \mathrm{i}>0$, and $\partial \mathrm{APV} / \partial r e d<0$.

Given differing red and $i$ structures per emission, the $\mathrm{APV}_{\mathrm{t}}$, and hence $\mathrm{MEV}_{\mathrm{t}}$, of bills from a given emission would differ across the circulation years of that emission, as well as across emissions in the same colony and between emissions of different colonies. As such, comparing the face value of bills over the circulation history of an emission, summing the face value of bills across emissions in a given colony, and summing the face value of bills across colonies are meaningless exercises. ${ }^{9}$ Paper money is not just paper money.

Given a market discount rate $(r)$ and assuming $(\mathrm{LP}-\mathrm{RD}) \approx 0$, colonial legislatures could control the market exchange value (MEV) of their paper money by controlling its APV through how they structured and executed red and by selecting an $i$. Using these tools, could colonial legislatures achieve their monetary goal of creating a stable paper money that always traded at its specie-equivalent face value or, barring that, always traded at a stable value relative to its specieequivalent face value or, barring that, at least traded at a predictably stable trend value relative to its specie-equivalent face value? The following sections explore these potentialities.

\section{REDEMPTION MECHANISMS FOR ZERO-COUPON BONDS}

Bills of credit that paid no $i$ and so functioned as zero-coupon bonds were the most 
typical emitted by colonial legislature. Three different redemption mechanisms were used, i.e. redemption through payment of future taxes, redemption through payment of loan principal, and redemption using an accumulated sinking fund. All three mechanisms produce a similar APV calculation, even though their administrative structures differ considerably. The Tax-Redemption Mechanism

The tax-redemption mechanism was the most ubiquitous, in part because it was used to meet wartime emergency spending. Colonial governments faced standard budget constraints. Tax receipts had to match spending. When they didn't, colonial governments had to adjust their borrowing and asset positions. For the most part, colonial governments did not have asset positions, such as stocks of gold and land. In addition, external markets where colonial governments could borrow and lend were not adequately developed or accessible. Thus, when current tax receipts did not match current spending, colonial governments moved tax receipts through time to balance current budgets.

They did this by issuing bills of credit (M), see equation (3). Local taxes could be paid in these bills or in specie at a legally fixed equivalence to bills for tax receipts. This rate would be the stated par or face value of the bills. Paper money creation was a credit-debt mechanism that matched budget deficits with budget surplus over a multi-year horizon. As such, the balanced budget requirement was cut loose from a strict time unit, such as always being balanced over the fiscal year. It still had to be balanced, but now it could be balanced over a multi-year horizon. To achieve this outcome, colonial paper money acts included concurrent tax legislation designed to remove the authorized bills emitted in the near future.

$$
0<\left(G_{j}-T_{j}\right)=M_{j} \leq \sum_{t=j+1}^{N}\left(T_{t}-G_{t}\right)>0
$$

$\mathrm{M}_{\mathrm{j}} \quad$ = face value of new emissions of $\mathrm{M}$ (bills of credit) in year $\mathrm{j}$ 
$\mathrm{T}=$ taxes paid in $\mathrm{M}$ or its specie equivalent at face value

$\mathrm{G} \quad$ = government spending

To maintain fiscal credibility, future taxes in excess of spending, $\left(T_{t}-G_{t}\right)>0$, had to be spread over numerous years, especially when $\mathrm{M}_{\mathrm{j}}$ was large such as from wartime emergency spending. This structure imparted a time-discounting dimension to the bills' APV. This timediscounting would typically vary with the size of $\mathrm{M}_{\mathrm{j}}$, which in turn depended on the size of the budgetary (wartime) emergency.

The typical method of tax-redemption was to set net new taxes to redeem $M_{j}$ to be an equal amount per year $\left(F_{t}\right)$ over the $N$-year redemption window, i.e. $\left(T_{t}-G_{t}\right) / N=F_{t}$ for years $j+1$ through $\mathrm{N}$. Under this condition, $\mathrm{M}_{\mathrm{j}}$ is removed from circulation at a constant rate over the Nyear redemption window. While setting redemption taxes at $\mathrm{F}_{\mathrm{t}}$ was the most typical, it was not universal. Often colonial government enacted small variations in $\mathrm{T}_{\mathrm{t}}$ over the $\mathrm{N}$-year redemption window. Thus, calculating the APV of each emission requires a unique exercise depending on that emission's explicit $T_{t}$ structure.

\section{The Land-Bank Loan Redemption Mechanism}

When colonial governments did not have enough emergency spending to serve as a basis for emitting new $\mathrm{M}$, they typically turned to a land-bank loan mechanism to emit new $\mathrm{M}$ into the economy. Bills of credit were printed and placed in the colony's treasury and subjects could borrow bills on interest, pledging their lands as collateral (Celia and Grubb 2014, Grubb 2015, Thayer 1953). Loan principal would be repaid to the treasury on a fixed schedule, thus removing the bills from circulation. See equation (4).

(4) $\quad \mathrm{M}_{\mathrm{j}}=\sum_{\mathrm{t}=\mathrm{j}+1}^{\mathrm{N}} \mathrm{L}_{\mathrm{t}}$

$\mathrm{L} \quad=$ loan principal paid (redeemed) each year 
This land-bank redemption mechanism imparted the same time-discounting structure to the bills for calculating a bill's APV as did the tax-redemption mechanism. The N-year redemption window could vary across emissions, thus yielding variation in the APV of bills from different emissions regardless of whether those emissions employed land-bank or tax-redemption mechanisms. Tax-redemption and land-bank-loan redemption mechanisms, however, may have had a differing effects on (LP - RD) in equation (1), see Grubb (2014).

The time structure of redemption was typically more varied across land-bank emissions than across tax-redemption emissions. Sometimes all the principal would be redeemed only in that last year of the loan period, i.e. $\mathrm{M}_{\mathrm{j}}=\mathrm{L}_{\mathrm{N}}$ with $\mathrm{L}_{\mathrm{t}}=0$ for $\mathrm{t}<\mathrm{N}$. More typical, and similar to the tax redemption mechanism, $\mathrm{L}_{\mathrm{t}}$ was set at a constant face value amount $\mathrm{L}_{\mathrm{t}}=\mathrm{L}_{\mathrm{t}} / \mathrm{N}$. In this case, $\mathrm{M}_{\mathrm{j}}$ was removed from circulation, and so the face value of the paper money supply shrank, at a constant rate over the $\mathrm{N}$-year loan redemption window. Often, however, colonial governments would re-loan the principal payments received during a designated portion of the loan period $\mathrm{N}$. This action kept the amount of bills in circulation constant at $\mathrm{M}_{\mathrm{j}}$ over that portion of the $\mathrm{N}$ period. Such patterns would alter the time-discounting calculations needed to determine APV. Again, calculating the APV of each emission requires a unique exercise depending on how that emission's $L_{t}$ was structured.

An additional issue affecting APV calculations for the land-bank loan mechanism is how the annual interest income earned $\left(E_{t}\right)$ from the loans was used by the colonial government, see equation (5). The annual interest subjects had to pay on their loans was a percentage point or two below the typical market rate. This incentivized subjects to borrow the bills and put them into circulation. Land-bank emissions always appear to be fully loaned out.

$$
i *\left[\sum_{\mathrm{t}}^{\mathrm{N}}\left(\mathrm{L}_{\mathrm{t}}\right)\right]=\mathrm{E}_{\mathrm{t}}
$$


$\mathrm{E} \quad=$ interest earnings each year

$i \quad=$ yearly interest charged on loans of $\mathrm{M}$

Some colonial governments used the interest income $\left(E_{t}\right)$ as current revenue and spent it on current salaries, etc. This revenue formed an important part of the spending revenue for some colonies, e.g. New Jersey, and allowed them to reduce current taxes (Grubb 2015). This action kept the bills paid in as annual interest in circulation. Thus, the money supply $\left(\mathrm{M}_{\mathrm{j}}\right)$ left in circulation would strictly follow the $\mathrm{L}_{\mathrm{t}}$-redemption process.

Some colonial governments, however, loaned the annual interest earned back out, thus increasing the principal to be redeemed by year $\mathrm{N}$ to more than the initial $\mathrm{M}_{\mathrm{j}}$ available to be loaned, e.g. Maryland after 1769 (Celia and Grubb 2014). This action did not alter the $\mathrm{M}_{\mathrm{j}}$ left in circulation or the APV calculation process. The only difference was, for colonies following this method, they would collect more specie income in year $\mathrm{N}$ because more principal was now outstanding than there were bills in circulation to pay that principal.

Finally, some colonies used the annual interest income to retire bills from circulation, e.g. see New Jersey in the 1720s (Grubb 2015). This process altered the APV calculation from those methods outlined above as it altered the path of $\mathrm{M}_{\mathrm{j}}$ left in circulation from that yielded by a strict $\mathrm{L}_{\mathrm{t}}$-redemption process. Again, calculating the APV of each emission requires a unique exercise depending on how that emission's $E_{t}$ was used.

\section{Sinking Fund Redemption Mechanism}

Using a sinking fund as a redemption mechanism was practiced primarily, if not solely, by Maryland. Given an amount of paper money $\left(\mathrm{M}_{\mathrm{j}}\right)$ emitted by the colonial government, taxes were concurrently legislated that were payable in specie over a number of years $\mathrm{j}+1$ to $\mathrm{N}$, with the proceeds placed in an interest-bearing fund. At $\mathrm{N}$, when the fund was expected to equal the amount of $\mathrm{M}_{\mathrm{j}}$ initially emitted, $\mathrm{M}_{\mathrm{j}}$ would be exchanged for the specie in the fund at M's face 
value in specie, see equation (6).

$$
\mathrm{M}_{\mathrm{j}} \leq \mathrm{S}_{\mathrm{N}}=\sum_{\mathrm{t}=\mathrm{j}+1}^{\mathrm{N}}\left[\left\{\left(\mathrm{T}_{\mathrm{t}}-\mathrm{G}_{\mathrm{t}}\right)=\mathrm{S}_{\mathrm{t}}\right\}+i^{*} \sum_{\mathrm{t}=\mathrm{j}+1}^{\mathrm{N}} \mathrm{S}_{\mathrm{t}+1}\right]
$$

$\mathrm{S} \quad=$ the sinking fund in specie-denominated assets

Compared with the tax-redemption and land-backed loan mechanisms, the taxes filling the sinking fund could not be paid in bills $\left(\mathrm{M}_{\mathrm{j}}\right)$. At maturity, however, the bills would be swapped at face value for specie-denominated assets, as opposed to being swapped at face value for specie-equivalent tax obligations or loan principal repayment obligations. This administrative difference, however, does not matter to the APV calculation given face value specie-equivalent redemption at maturity for each mechanism. As such, the sinking fund mechanism yields the same APV calculations as the special case of the tax-redemption and land-backed loan redemption mechanisms when all redemptions are structured to take place in year $\mathrm{N}$ and none in the intermediate years between $\mathrm{j}+1$ and $\mathrm{N}$.

\section{Calculating $A P V_{t}$}

If redemption takes place only in year $\mathrm{N}$, then the $\mathrm{APV}_{\mathrm{t}}$ of a bill is simply $e^{-\mathrm{rt}}$ where $\mathrm{r}=$ the discount rate. In year $\mathrm{N}(\mathrm{N}=0)$, namely at the point of redemption, $\mathrm{APV}_{\mathrm{N}}=1$, i.e. its face value in specie. At five years before $\mathrm{N}$, namely five years prior to redemption, with a 6 percent discount rate, $\mathrm{APV}_{5}=.74$, i.e. the bill is worth 74 percent of its face value in specie. Figure 1 shows the time-discounted path of a bill's APV $_{t}$, using a 6 percent discount, for a new bill that is redeemable 10 years later. ${ }^{10}$ The bill's $\mathrm{APV}_{\mathrm{t}}$ starts at 55 percent of face value when issued and slowly rises to face value 10 years later at the point of redemption. This is simply timediscounting, not depreciation. Under this method, the legislature cannot structure the redemption of bills to always have them trade at face value. They will only trade at face value at the point of redemption (maturity). The $A P V_{t}$ for this redemption structure is certain. There is no range of 


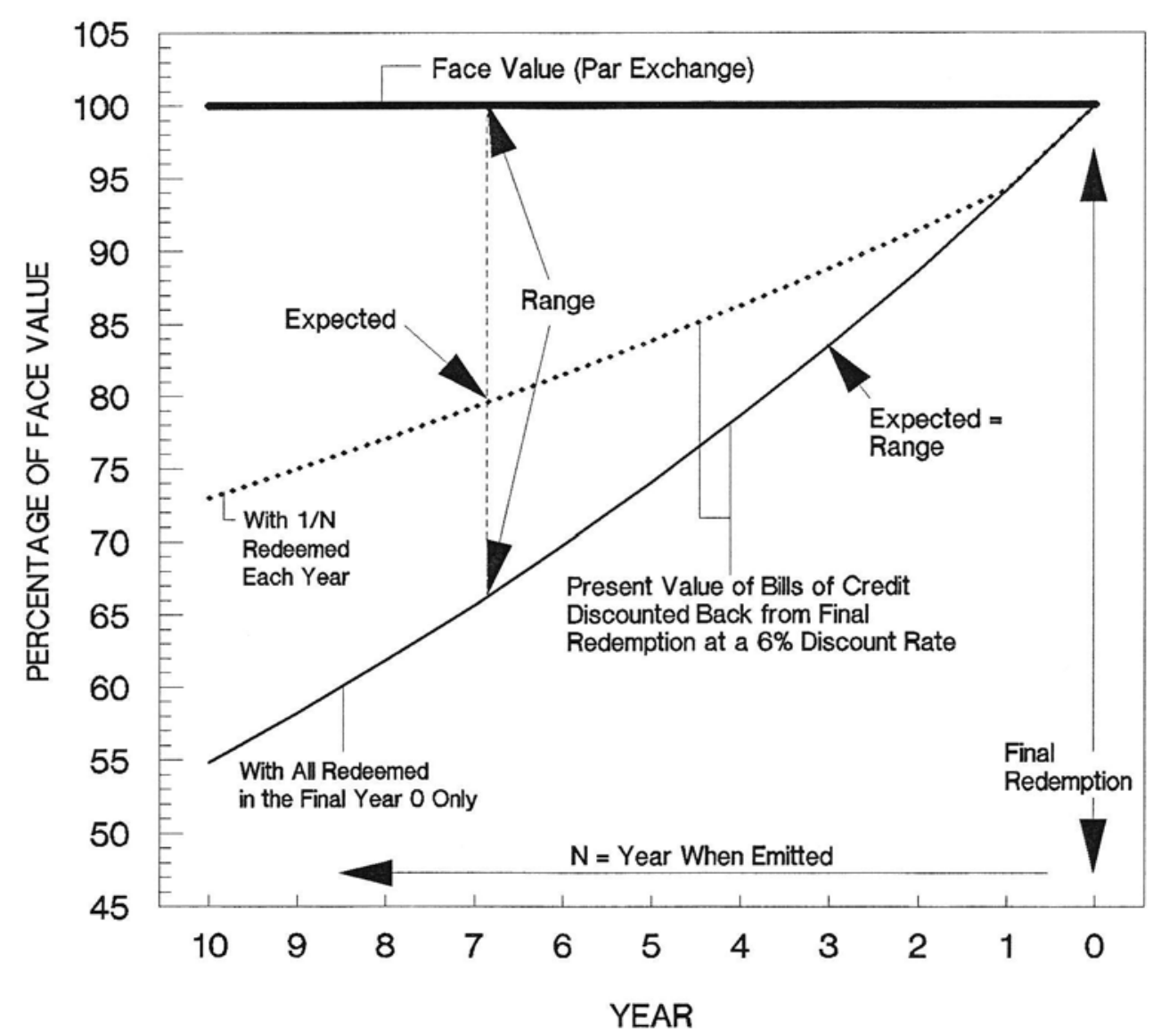

Figure 1. Present Value of Bills of Credit between Emission and Redemption

values around its solid-line path in Figure 1.

If bills are redeemed at some rate $k_{t}$ over the redemption window $j+1$ to $N$, then $A P V_{t}$ is calculated as shown in equation (7). The outcome when $\mathrm{k}_{\mathrm{t}}$ is a constant, namely $1 / \mathrm{N}$, is shown in Figure 1 as the $1 / \mathrm{N}$ dotted line. This redemption structure pushes $A P V_{t}$ closer to trading at face value than when redemption is in year $\mathrm{N}$ only. However, it still cannot achieve bills trading at face value except in year N. Again, this below-face-value outcome is not depreciation, but simply time-discounting, i.e. rational bond pricing.

$$
\begin{aligned}
& \text { (7) } \mathrm{APV}_{\mathrm{t}}=\sum_{\mathrm{t}}^{\mathrm{N}} \mathrm{k}_{\mathrm{t}} * e^{-\mathrm{rt}} \\
& \mathrm{k}_{\mathrm{t}} \quad=\text { share of } \mathrm{M}_{\mathrm{j}} \text { redeemed each year }\left(\mathrm{M}_{\mathrm{t}} / \mathrm{M}_{\mathrm{j}}\right) \text { from } \mathrm{j}+1 \text { to } \mathrm{N} \text {, with } \sum_{\mathrm{t}=\mathrm{j}+1}^{\mathrm{N}}\left(\mathrm{k}_{\mathrm{t}}\right)=1
\end{aligned}
$$


While pushing $\mathrm{APV}_{\mathrm{t}}$ closer to face value than the redemption at N-only structure, this 1/N redemption mechanism comes with a cost. Paper money acts did not indicate which bill from an emission would be redeemed in which year within its $\mathrm{j}+1$ to $\mathrm{N}$ redemption window. Thus, the dotted line in Figure 1 showing the $\mathrm{APV}_{\mathrm{t}}$ path for the $1 / \mathrm{N}$ redemption structure is only the expected present value or the $\mathrm{APV}_{\mathrm{t}}$ of a representative bill currently outstanding in year $\mathrm{t}$. The range around that expected present value, at any point in time, extends from face value to the solid line showing the $\mathrm{APV}_{\mathrm{t}}$ for the redemption at N-only structure. This range of values makes for a cumbersome medium of exchange.

Using an approximate $1 / \mathrm{N}$ per year redemption structure may have been necessary to achieve fiscal credibility. The 1/N structure is consistent with a fiscal obligation smoothing strategy, revealing a credible commitment to keeping taxes and loan principal repayments within historically acceptable and feasible yearly limits. Most colonies relied on a redemption mechanism close to the $1 / \mathrm{N}$ per year method.

Did Colonists Understand the Necessity of Time-discounting Zero-coupon Bonds?

Subjects understood the necessity of time-discounting bills of credit that were structured as zero-coupon bonds. For example, in the New Jersey provincial council in 1758, Lewis M. Ashfield based his objection to paper money on the time-discounting properties of these bills and the effect that a lengthy redemption had on their present value. He said, “...as the whole Credit of a Paper Currency depends upon its Sinking [redemption], which by being put off to a long day will he Conceives greatly Contribute to Lessen it’s Value...” (Ricord 1892 17, p. 159).

In 1764, Benjamin Franklin, in the longest speech of his career (among his surviving texts), explained to the Pennsylvania Assembly exactly how bills of credit structured as zerocoupon bonds worked in terms of time-discounting and present value. In reference to an 
emission of 50,000£ $£_{\mathrm{PA}}$ in Pennsylvania bills of credit proposed in late 1763, Franklin pointed out

"The true Way in my Opinion to preserve a Value in our Paper Bills nearly equal to the nominal

Sums we stamp on them...” He argued that the method of tax-redemption at future dates could

not achieve this outcome because of time-discounting. He stated,

At present every Bill that I receive tells me a Lie, and would cheat me too if I was not too well Acquainted with it. Thirty Shillings in our Bills, according to the Account they give of themselves should be worth five Dollars; and we find them worth but four: They should be worth 22s. $6 d$. Sterling, and we find them worth scarce 17s. $2 d$. Sometimes indeed more or less... When we sit here in Legislation, we have great Power, but we are not almighty. We cannot alter the Nature of Things. Values will be as they are valued or valuable, and not as we call them. We may stamp on a Piece of Paper, This is Ten Shillings, but if we do not make some other Provision that it always be worth Ten Shillings, the Say-so of our Law will signify little. Experience in other Colonies as well as in ours, have demonstrated this.

...we propose to found the Credit of these Bills on a Tax to be raised, which is to sink them as I understand in Six Years at one Sixth Part per Annum, for the due punctual Performance of which there is to be the Sanction of a Law. If this be the Case, and allowing the Security to be good, of which I make not the least Doubt, (tho' some Colonies have by subsequent Laws postpon'd the Payments they had engaged to make, for much longer Terms) I say, supposing the Law punctually executed, it is not difficult... to compute what real Value that Fund [the proposed tax redemption] gives the Bills. When you pay them out, it is instead of so much real Money which your owe and ought to pay immediately, but not having the Money to pay, these are your Promisory Notes, obliging you to pay the whole Sum, not upon Demand, but in Six Years by annual Quotas; they are therefore in the nature of things, and between honest Men, really worth no more than the Sum that remains, when Interest for the Time is deducted; and allowing that publick Security is something better than private, I shall state that Interest at 5 per Cent only; then

The Interest of $£ 50,000$ for the first Year is

Do of 41,666: 13:4

Do of 33,333: $6: 8$

$2 \mathrm{~d}$ Year is

3d Year is

£2500: $0: 0$

Do of 25,000: $0: 0$

4th Year is

2083: $6: 8$

Do of 16,666: $13: 4$

5th Year is

1666: $13: 4$

Do of $8,333: \quad 6: 8$

6th Year is

1250: $0: 0$

833: $6: 8$

416: $13: 4$

Total of Interest

£8750: $0: 0$

This Sum, £8750, taken from $£ 50,000$

8,750

leaves $£ 41,250$ for the true Value of the promisory Notes, or we call them, Bills of Credit, which is always 20 per Cent less than their nominal 
Value; and if People should compute the Interest at 6 per Cent instead of 5, and have withal any reason to doubt the Punctuality of the Government as to the Time of Payment, their Value would be proportionally lower. (Labaree 1967, v. 11, pp. 13-15).

While presented differently by Franklin, when his numbers are recalculated to be percentages of face value between emission and final redemption, they are the same as depicted in Figure 1.

In 1767, Franklin explained to the British how colonial bills of credit structured as zerocoupon bonds functioned as money. In a paper titled "The Legal Tender of Paper Money in America,” presented to a Ministry in Britain on 13 February 1767, Franklin wrote,

....a Bill [of credit] promising Payment at Distant Periods of Time,...depending solely on such distant Payment for its Value, how good soever the Security that the Payment shall be punctually made, is not and cannot possibly be of Value equal to the Sum expressed in it [on its face], but must suffer a Discount in Proportion to the Time. Hence the Discount will be greatest soon after the Bills are issued, that is, as soon as the Nature of them begins to be understood; and, as the Term of Payment approaches, the Discount will gradually become less till it amounts to nothing worth Notice.

But such a daily changing Medium is from that Circumstance inconvenient and unfit for the Purposes of Commerce, whose Measures ought to be as much as possible fixed and certain, and easily understood, the common People being incapable of nice Computations (Labaree 1970, v. 14, pp. 35-6).

Besides describing the $\mathrm{APV}_{\mathrm{t}}$ time-path of a bill as shown in Figure 1, Franklin also noted how the necessity of time-discounting made for a cumbersome medium of exchange.

In 1776, Adam Smith, in the Wealth of Nations, made similar observations which, like

Franklin's, are consistent with the model depicted in Figure 1. Smith wrote,

The paper currencies of North America consisted, not of bank notes payable to the bearer on demand, but in a government paper, of which the payment was not exigible till several years after it was issued: And...the colony governments paid no interest to the holders of this paper,... But allowing the colony security to be perfectly good, a hundred pounds payable fifteen years hence, for example, in a country where interest is at six per cent. is worth little more than forty pounds ready money.... (Smith 1937, pp. 310-12).

Finally, bills of exchange were a familiar and commonly used private payment instrument within the transatlantic merchant community. The face value of a bill of exchange was its payment at some designated future date at some designated distant location. Bills of 
exchange were discounted, i.e. sold below their face value, with the difference between the face value and the sale price capturing the implicit interest, transaction, and risk costs of carrying the bill to execution. Everyone understood this. Bills of credit were structured the same way, and so the public would have been familiar with how to assess their present value.

\section{OVERLAPPING ZERO-COUPON BOND REDEMPTION STRUCTURES}

Monetary emissions were not one-off exercises. Once the redemption exercise had removed an emission from circulation, another would soon take its place. Typically, colonies would authorize a new emission before the prior emission had been removed from circulation, thus operating overlapping emission-redemption structures. Figure 1 shows that bills of credit structured as zero-coupon bonds would never trade at face value except at the point of redemption, nor would they ever trade at a constant value relative to their face value. Could overlapping emission structures improve this outcome?

Figures 2, 3, and 4 model the outcome of such sequential and overlapping emissionredemption structures. These models are ideally structured monetary policies used to illustrate what colonial legislatures could potentially achieve. Figures 2, 3, and 4 maintain the same assumptions used to construct Figure 1, and use the 1/N yearly redemption structure. Figures 2, 3, and 4 expand Figure 1 to make the process sequential and overlapping. The only differences are that Figure 2 assumes that the redemption interval for each emission is four years with 1/4th redeemed each year, Figure 3 assumes that the redemption interval is ten years with 1/10th redeemed each year, and Figure 4 assumes that the redemption interval is 16 years with 1/16th redeemed each year. In addition, the horizontal scales of Figures 2, 3, and 4 are reoriented to be forward looking as opposed to retrospective as in Figure 1.

Sequential emissions impart an oscillating present value to the bills; the longer the 


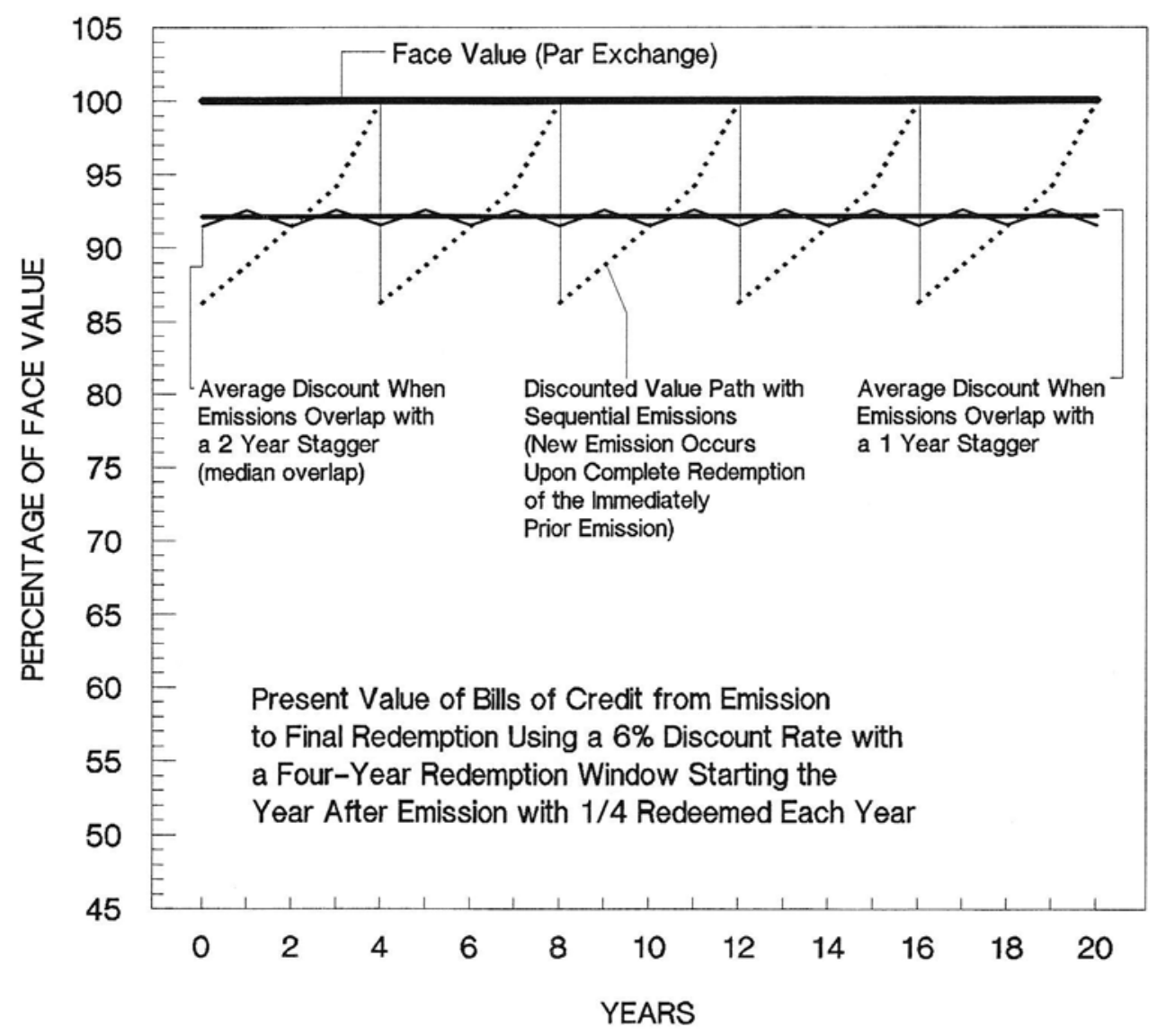

Figure 2. $\quad$ Present Value of Bills of Credit between Emission and Redemption with a Four-Year Emission Redemption Window, and with Sequential and Staggered Overlapping Emissions

emission-to-final-redemption time interval, the more amplified the oscillation. When emissions are perfectly sequential with no overlap, the four-year redemption window in Figure 2 has the present value of its bills cycling between 86 percent and 100 percent of face value, the ten-year redemption window in Figure 3 between 73 percent and 100 percent of face value, and the 16year redemption window in Figure 4 between 62 percent and 100 percent of face value. Such instability, even if perfectly predictable, is not a desirable feature for an easy-to-use medium of exchange. The above oscillation can be dampened by having emissions overlap.

Overlapping emissions with a one-year stagger perfectly stabilizes the present value of the average bill to a constant value over time, 92 percent of face value for emissions with a four- 


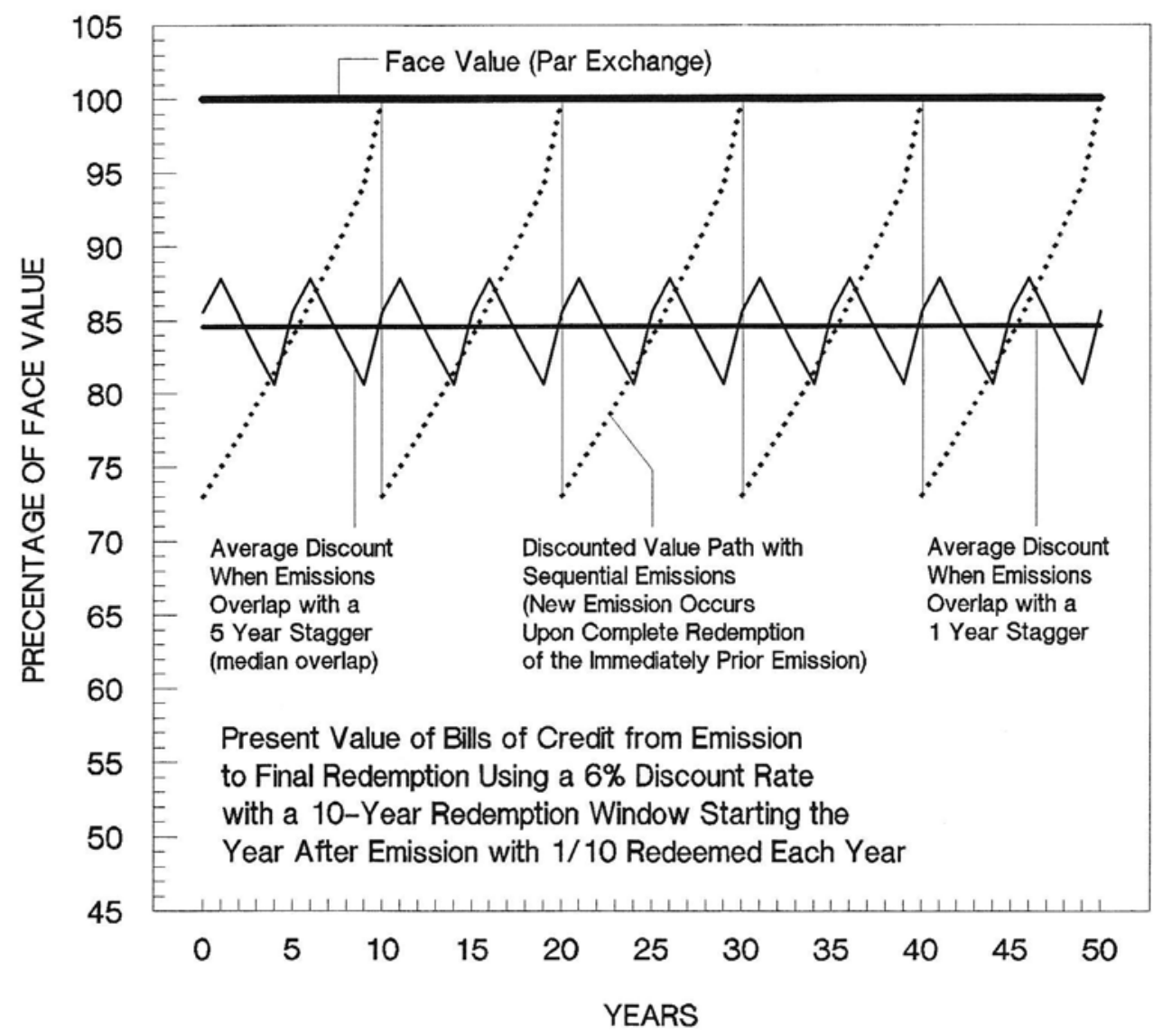

Figure 3. Present Value of Bills of Credit between Emission and Redemption with a Ten-Year Emission Redemption Window, and with Sequential and Staggered Overlapping Emissions

year redemption window, 84 percent with a ten-year redemption window, and 77 percent with a 16-year redemption window. Even overlapping emission-redemption structures that are half the emission-redemption window, substantially reduces the oscillation from a no-overlap structure. In Figure 2, a median overlap stagger yields a cycle between 91 and 93 percent of face value for emissions with a four-year redemption window. In Figure 3, a median overlap stagger yields a cycle between 81 and 88 percent of face value for emissions with a ten- year redemption window. In Figure 4, a median overlap stagger yields a cycle between 70 and 84 percent of face value for emissions with a 16-year redemption window.

Statistically, the patterns in Figures 2, 3, and 4 are either perfectly constant or stationary 


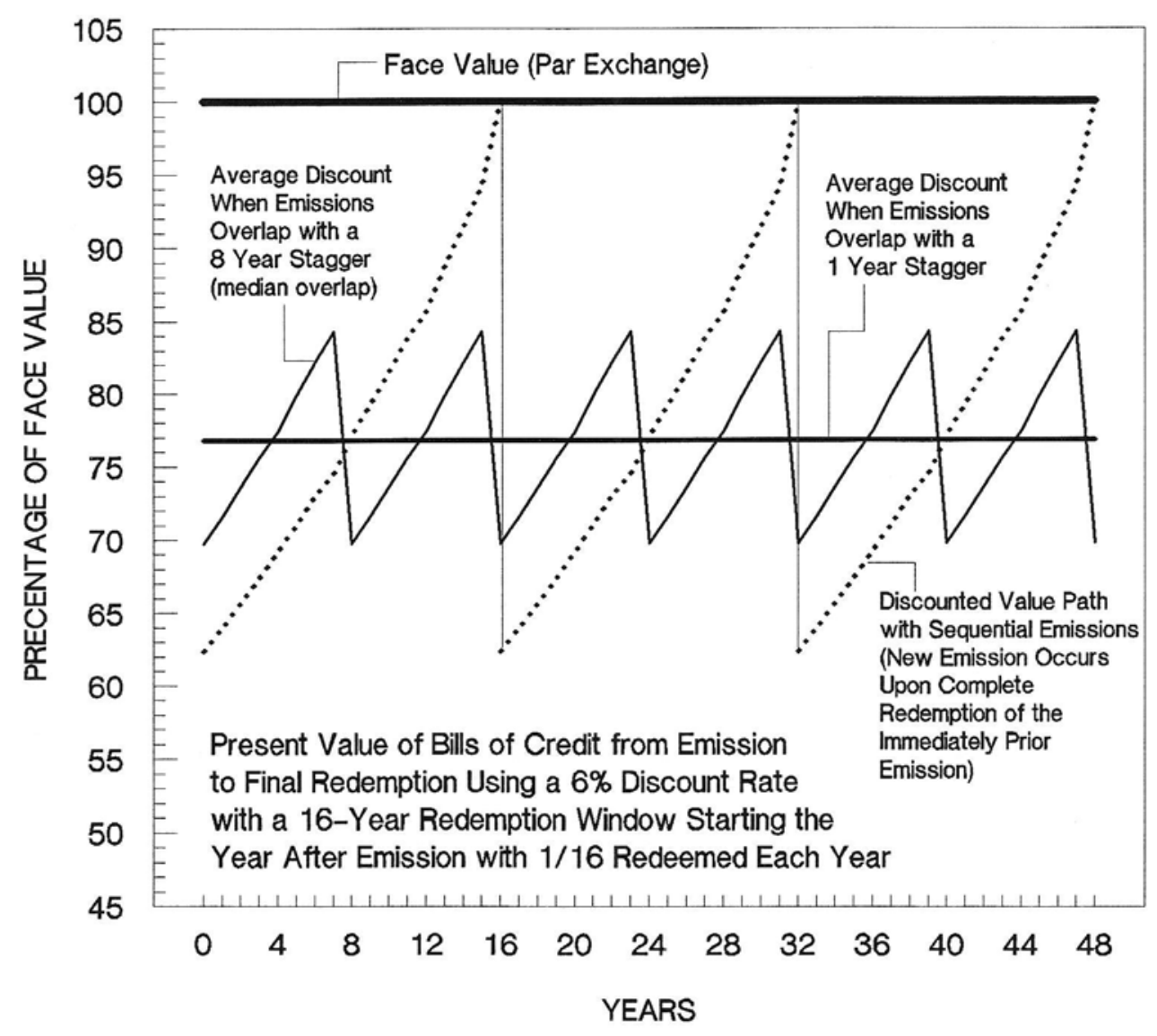

Figure 4. Present Value of Bills of Credit between Emission and Redemption with a 16-Year Emission Redemption Window, and with Sequential and Staggered Overlapping Emissions

with no trend and short half-lives. While Figures 2, 3, and 4 are stylized models, they can be used to gauge value patterns from alternative redemption windows and emission overlap staggers as shown in Appendix Table A1. Densely overlapping emission-redemption structures could produce predictable and relatively stable present value patterns for the average bill in circulation.

A complicating issue with overlapping emissions is that each emission was dated and distinguishable. Thus, while the average of all bills in current circulation might have a stable value, the present value of bills from different emissions currently in circulation could differ. Such variation in current values across bills from different, but overlapping, emissions would make a cumbersome medium of exchange. Colonial legislatures overcame this complication by 
making redemption requirements fungible across bills of different emissions that were concurrently in circulation. As long as the sequence of total redemption requirements over time equaled the sequence of total emitted bills over time, which bills were used to pay which taxes or loan obligations in which years, among overlapping emissions, would not matter. In most cases, redemption structures in paper money acts did not specifically designate which bills currently outstanding could satisfy the redemption requirements for that emissions. As such, fungibility among bills from overlapping and currently outstanding emissions appears to have been the norm for redemption. Legal tender laws explicitly allowed this fungibility.

In conclusion, colonial legislatures could not emit a bill of credit as a zero-coupon bond that would always trade at its face value. They could, however, create an overlapping emissionredemption structure for these bills that would cause the average bill to trade at or near a constant value relative to its specie-equivalent face value. Statistically, this pattern would be a stationary series with short half-lives to shocks.

\section{THE EMPIRICAL VALUE OF ZERO-COUPON BILLS OF CREDIT}

Appendix Table A1 shows that colonial legislatures frequently created overlapping emission-redemption structures. The realities and exigencies of colonial politics, foreign wars, and disputes with proprietors (and the British Board of Trade) made achieving the stylized model outcomes in Figures 2, 3, and 4 unlikely. Despite these real-world impediments, were colonial legislatures able to produce, via overlapping emission-redemption structures, reasonably functioning paper money regimes? Could they cause their bills to circulate at or near a constant value relative to their specie-equivalent face values?

The market exchange values (MEV in equation 1) of bills emitted by the middle colonies, from New York through Virginia, are used to judge whether value patterns are consistent with 
the stylized models in Figures 2, 3, and 4. These colonies are chosen because they primarily issued their bills as zero-coupon bonds and operated under the same legal tender regime. ${ }^{11}$ The complete MEV histories of the respective paper money emissions for New York, New Jersey, Pennsylvania, Maryland, and Virginia are used.

Observed market exchange rates are taken primarily from merchant account books. These rates are for exchanging colonies' bills of credit for bills of exchange paying pounds sterling in London. These exchange rates divided by the specie-equivalent face value of the bills of credit yields a preliminary measure of MEV. Face value is 1.3275 colonial pounds equals $1 £_{\text {sterling }}$ (Queen Anne’s Proclamation Rate) for New Jersey, New York, Pennsylvania, and Maryland pre-

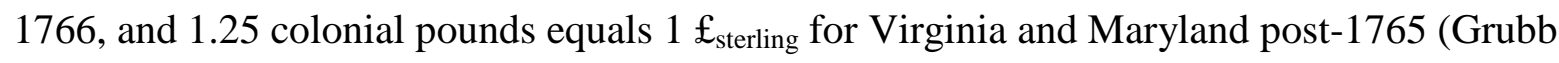
2014, McCusker 1978).

These data are adjusted to account for the time and transaction costs of getting a bill of exchange to London and having it liquidated into specie usable in the colonies. This cost is estimated to be approximately 7.09 percent. ${ }^{12}$ Thus, the final MEV estimate divides the observed market exchange rates in Grubb (2014) and McCusker (1978) by the realized par exchange rate of $1.2334 £_{\text {colonial pounds }}=1 £_{S}$ rather than $1.3275 £_{\text {colonial pounds }}=1 £_{S}$, and $1.1614 £_{\text {colonial pounds }}=1 £_{\mathrm{S}}$ rather than $1.25 £_{\text {colonial pounds }}=1 £_{\mathrm{S}}$, respectively. These final MEV estimates by colony are presented in Figure 5.

The empirical patterns in Figure 5 have a general resemblance to the stylized models in Figures 2, 3, and 4 once the actual redemption structures in Appendix Table A1 are taken into account. New York, New Jersey, and Pennsylvania employed a mixture of moderate to longish redemption windows, using an approximate $1 / \mathrm{N}$ redemption method per emission, and with moderate degrees of overlap between emissions. The redemption pattern is a mixture of those in 


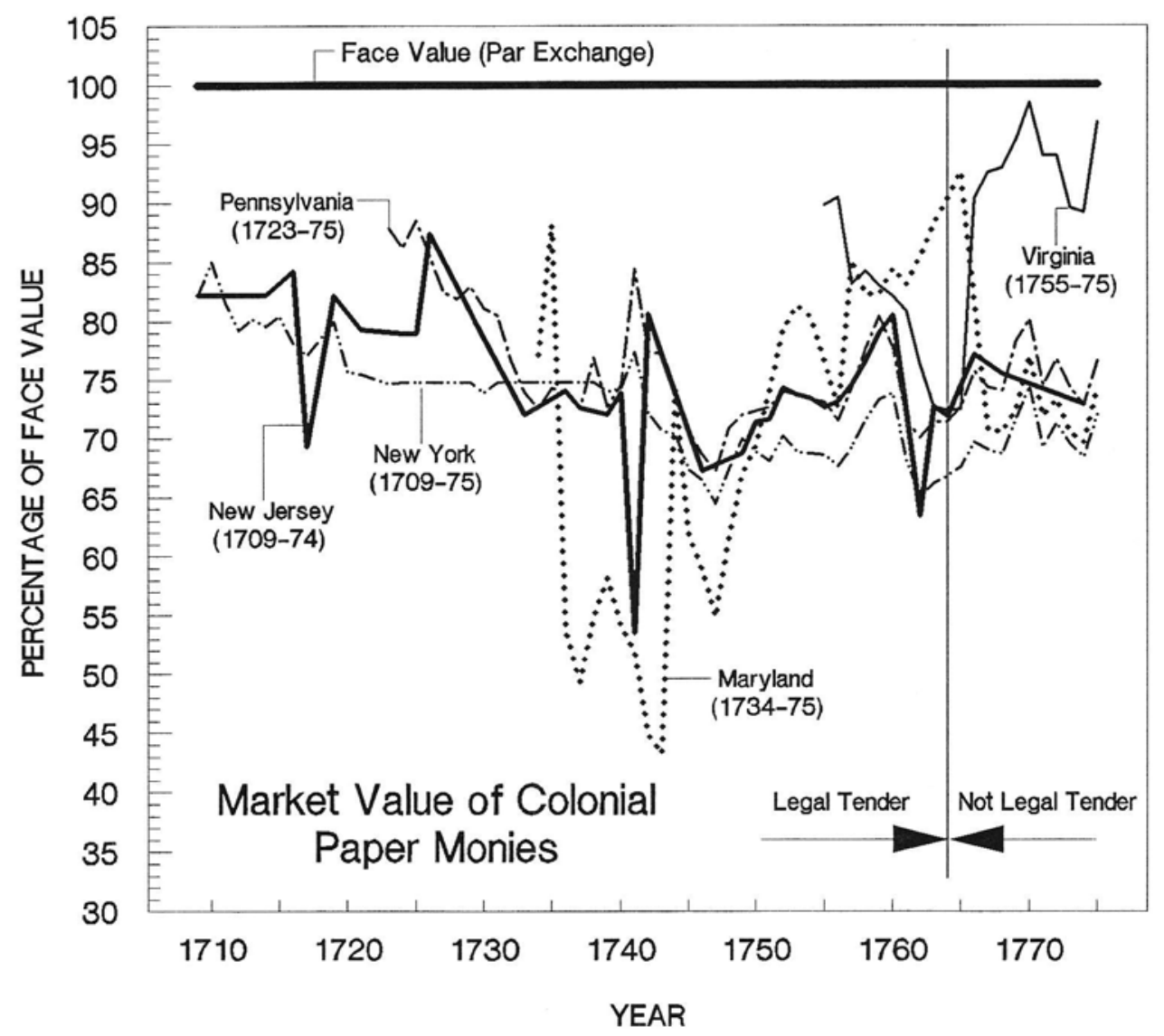

Figure 5. The Market Value of Bills of Credit Structured as Zero-Coupon Bonds as a Percentage of Specie-Equivalent Face Value Adjusted for Transaction Costs

Sources: Grubb (2015, 2014); McCusker (1978).

Notes: See text for construction. Linear interpolated values are used in place of missing observations.

Figures 2, 3, and 4, with a general movement from a Figure 2 pattern to a Figure 3 pattern to a Figure 4 pattern over time. For these three colonies, MEV primarily bounces between 85 and 65 percent of face value, with a slight downward trend over time. This range is where the typical average redemption window length would place its APV given the inconstant overlap of emissions enacted by their legislatures. The downward trend is consistent with the increase in the average redemption window length that occurs over time, in part due to the excessive cost of the Seven Years War. Large wartime emissions required longer redemption windows to keep yearly taxes within historically acceptable and feasible limits and so maintain fiscal credibility. 
Maryland provides a sharp contrast in MEV pattern over time, but one that is still generally consistent with the stylized model in Figure 1. From 1733 to 1765, Maryland employed a long redemption windows (31 years for most bills) with little emission overlap, and with most bills redeemed in the last year of the redemption window only. Once subjects learned of this structure, the MEV of Maryland bills fell to around 45 to 55 percent of face value and then more or less rose steadily toward face value by the final redemption year of 1765 . This pattern is within the general range of where the actual redemption structure would place its APV pattern over time, see Figure 1, Appendix Table A1, and Grubb (2008).

After 1765, Maryland switched to a shorter redemption window, but one that was still moderately long (12 years), with moderately overlapping emissions, i.e. between a Figure 3 and Figure 4 pattern. This change in redemption structure after 1765 made the MEV for Maryland bills look like that for New York, New Jersey, and Pennsylvania. The redemption structures for all four colonies after 1765 yields APVs in the general range of the observed MEVs of the bills for these colonies, which was around 70 to 80 percent of face value, see Figure 5 . These redemption structures fell between the stylized value patterns shown in Figures 3 and 4.

Virginia is an intriguing case, but one that still is generally consistent with modeled APV explaining the movements in the MEV of Virginia bills. Virginia’s MEV starts at around 90 percent of face value in 1755-6, plummets to around 75 percent of face value by 1765, and then by the early 1770s is back to around 90 to 95 percent of face value. This pattern is generally consistent with how the APV of Virginia's bills would move given changes in the redemption structure of Virginia's emissions over time. ${ }^{13}$ Virginia's emissions in $1755-6$ and the early 1770s had short redemption windows with a tight overlapping structure. Their APV would be close to that depicted in Figure 2, which approximates the MEV for Virginia's bills in these 
years.

In 1757 through 1762, Virginia switched to a moderately long redemption window, closer to the APV outcomes in Figures 3 and 4 than the APV outcome in Figure 2. This APV is broadly consistent with the MEV of Virginia's bills in Figure 5. Overall, movements of the APV of bills, caused by changes in redemption structures over time, can explain the movements of the MEV of Virginia’s bills over time. No other explanation is needed. ${ }^{14}$

Table 1 reports the time-series properties of the MEV data in Figure 5. The MEV for each colony is a trend stationary series with a structural break at 1764 or 1765 . The half-life to shocks is reasonably short, under 1.72 years for all the colonies and under 0.78 years for three of the colonies. Except for Maryland, the pre-1765 trend is negative, statistically significant, but small in magnitude. The pre-1765 trend in Maryland is positive, statistically significant, and large in magnitude. The post-1765 trends are sign-reversed in each colony from their respective pre-1765 pattern, statistically significant, but small in coefficient magnitude.

The results in Table 1 are consist with colonial legislatures crafting redemption structures to achieve a stable pattern for their bills’ APV, and hence MEV, over time. The small negative trend is largely the results of the timing of the Seven Years War, and the emission-redemption adaptations required to finance that war. While colonial legislatures could not achieve an ideal inside money that always traded at face value or at a constant value relative to its face value, they were able to control the APV of their bills enough to produce a paper money that traded at a predictably stable trend value relative to its face value over time.

Table 1 and Figure 5 can also be used to determine the likely impact on the MEV of bills caused by the 1764 Currency Act. Two major events happen in 1764, namely the end of the Seven Years/French and Indian War and the passage of the 1764 Currency Act. Disentangling 
these two events can be done with the evidence in Table 1 and Figure 5. First, the MEV in Figure

Table 1. Time Series Properties of the Market Exchange Value (MEV) of Colonial Paper Money, 1709-1775

\begin{tabular}{|c|c|c|c|c|c|}
\hline \multirow{2}{*}{$\begin{array}{l}\text { Independent } \\
\text { Variables }\end{array}$} & \multirow[b]{2}{*}{ New York } & \multicolumn{3}{|c|}{ Dependent Variable: $\left(\mathrm{MEV}_{\mathrm{t}}-\mathrm{MEV}_{\mathrm{t}-1}\right)$} & \multirow[b]{2}{*}{ Virginia } \\
\hline & & New Jersey & Pennsylvania & Maryland & \\
\hline Constant & $\begin{array}{l}189.8089 * * * \\
(56.8560)\end{array}$ & $\begin{array}{l}311.9681^{* * * *} \\
(86.2115)\end{array}$ & $\begin{array}{r}146.0683 * \\
(0.0995)\end{array}$ & $\begin{array}{l}-1927.9940 * * * \\
(282.3685)\end{array}$ & $\begin{array}{l}\text { 1339.1400*** } \\
(433.5551)\end{array}$ \\
\hline $\mathrm{MEV}_{\mathrm{t}-1}$ & $\begin{array}{l}-0.3913 * * \\
(0.0989)\end{array}$ & $\begin{array}{l}-0.6984 * * * \\
(0.1215)\end{array}$ & $\begin{array}{l}-0.3312 * \\
(0.0995)\end{array}$ & $\begin{array}{l}-0.7213 * * * \\
(0.1036)\end{array}$ & $\begin{array}{l}-0.5955 * * * \\
(0.1110)\end{array}$ \\
\hline Year & $\begin{array}{l}-0.0928 * * * \\
(0.0291)\end{array}$ & $\begin{array}{l}-0.1492 * * * \\
(0.0464)\end{array}$ & $\begin{array}{l}-0.0695+ \\
(0.0459)\end{array}$ & $\begin{array}{l}1.1302^{* * *} \\
(0.1641)\end{array}$ & $\begin{array}{l}-0.7341^{* * *} \\
(0.2450)\end{array}$ \\
\hline $\mathrm{D}$ & $\begin{array}{l}2.3730^{* *} \\
(0.9247)\end{array}$ & $\begin{array}{l}4.2918 * * \\
(2.1025)\end{array}$ & $\begin{array}{l}2.3044+ \\
(1.469)\end{array}$ & $\begin{array}{c}-20.6413 * * * \\
(3.5953)\end{array}$ & $\begin{array}{l}17.0178 * * * \\
(3.1831)\end{array}$ \\
\hline (or) & & & & & \\
\hline$D^{*}$ Year & $\begin{array}{l}0.0013^{* *} \\
(0.0005)\end{array}$ & $\begin{array}{l}0.0024 * * \\
(0.0012)\end{array}$ & $\begin{array}{c}0.0013+ \\
(0.0008)\end{array}$ & $\begin{array}{l}-0.0117 * * * \\
(0.0020)\end{array}$ & $\begin{array}{l}0.0097 * * * \\
(0.0018)\end{array}$ \\
\hline $\begin{array}{l}\text { \# of Dependent } \\
\text { Variable Lags }\end{array}$ & 0 & 0 & 0 & 1 & 0 \\
\hline $\mathrm{N}$ & 66 & 65 & 52 & 40 & 20 \\
\hline Years Spanned & $1709-1775$ & $1709-1774$ & $1723-1775$ & 1734-1775 & $1755-1775$ \\
\hline Adjusted $\mathrm{R}^{2}$ & 0.18 & 0.32 & 0.15 & 0.59 & 0.67 \\
\hline $\mathrm{F}$ & $5.96 * * *$ & $11.02 * * *$ & $4.13^{* *}$ & $15.22 * * *$ & $13.75^{* * *}$ \\
\hline Half-life in Years & 1.40 & 0.58 & 1.72 & 0.54 & 0.77 \\
\hline
\end{tabular}

Sources: The raw data are from Grubb (2014) and McCusker (1978) which were then transformed as described in the text.

Notes: Data are annual. Standard errors are in parentheses under their respective coefficients. Dickey-Fuller critical values are used for the $\mathrm{MEV}_{\mathrm{t}-1}$ coefficients, see Enders (1995, p. 419). For all regressions, serial correlation was corrected by adding lags of the dependent variable until the Durbin's Alternative Tests for autocorrelation failed to reject the hypothesis of no serial correlation above the 0.1 level. The half-life is calculated using the following equation: $\left[-\ln (2) / \ln \left(1+a_{1}\right)\right.$ ], where $\mathrm{a}_{1}$ is the coefficient on the $\mathrm{MEV}_{\mathrm{t}-1}$ independent variable. See Mark (2001, p. 32). For New Jersey and Pennsylvania, D = 1 for the years 1765-1775 and zero otherwise. For New York, Maryland, and Virginia, D = 1 for the years 1766-1775 and zero otherwise. D is a structural break capturing a change in monetary regimes due both to the 1764 Currency Act (end of legal tender designation) and the end of war financing pressure with the conclusion of the Seven Years War. The D selected yielded a local maximum regression fit. If the initial year for D is moved one year forward or one year backward from that reported here the regression fit is reduced. Either D or (D*Year) are used but not both together. The other coefficients, their statistical significance, and the regression fit are not affected by this choice.

$* * *$ indicates significance above the 0.01 level.

** indicates significance above the 0.05 level.

* indicates significance above the 0.1 level.

+ indicates significance above the 0.15 level. 
5 for New York, New Jersey, and Pennsylvania from 1750 through 1755 is hard to distinguish from 1765 through 1774.

Second, the change in legal tender powers affected all colonies in Figure 5 equally, but the trend shift in MEV in 1764 was not in the same direction for all colonies. Maryland moved the opposite of the rest. Maryland was also the only colony that financed its participation in the Seven Years War differently, relying less on emitting bills to cover expenses. Maryland, unlike the other colonies in Figure 5, received no Parliamentary reimbursements to offset their contributions to that war (Greene 1980, p. 98). This finding is consistent with the exigencies of financing of the Seven Years War causing the structural break in MEV in 1765-6 and not the 1764 Currency Act. The logic behind why legal tender laws did not affect MEV is presented below in the section on Legal Tender Laws.

In conclusion, treating the paper money of most colonies as zero-coupon bonds rather than as fiat currency, and assuming its value is primarily determined by its asset present value, is consistent enough with the empirical evidence to warrant adoption and expansion of this approach. In other words, assuming that $(\mathrm{LP}-\mathrm{RD}) \approx 0$ and so $\mathrm{MEV} \approx \mathrm{APV}$ is broadly consistent with the empirical evidence, and so represents a promising new approach to understanding colonial paper money. The next step is to do the extensive work needed to exactly establish the redemption structures in each paper money emission, and then estimate how well the exact measure of $\mathrm{APV}_{\mathrm{t}}$ tracks $\mathrm{MEV}_{\mathrm{t}}$ through time in each colony. So far this has only been done for New Jersey and post-1765 Maryland (Celia and Grubb 2014; Grubb 2014, 2015). These studies support the promise of the approach articulated here.

\section{INTEREST-BEARING BILLS OF CREDIT}

Emitting a bill of credit whose value remained constant at its face value could be 
achieved by having the bill pay annual interest at the market interest rate. Figure 6 models the effect of adding annual interest payments to the present value of bills supported otherwise only by a redemption mechanism. All the assumptions in Figure 1 are carried through into Figure 6, except that 6 percent annual interest payments are made to the current holder of the bill. Payments have to be paid annually, as opposed to paid as an accumulated lump sum in the final redemption year. In addition, interest payments have to be separated and extracted from the bills themselves, as opposed to attached permanently to their face.

Other things equal, paying this annual interest pushes the present value of the bills, measured at annual intervals just before the interest is paid, to within 99 percent of their face value for all years $\mathrm{j}$ to $\mathrm{N}$. As long as annual interest comparable to the market discount rate is paid, it does not matter whether redemption is in year $\mathrm{N}$ only or at the rate of $1 / \mathrm{N}$ per year. It also does not matter whether the emission-redemption window is a few years or many years. Bills will circulate for almost exactly their face value in all years.

Interest-bearing bills were occasionally used in the colonies, mostly after 1750 in New England and briefly in North Carolina and Virginia in the mid-1750s, see Appendix Table A1. In 1764, Benjamin Franklin, in the longest speech of his career (among his surviving texts), advocated this mechanism for supporting the value of bills of credit. A key point of this speech was to advocate to the Pennsylvania Assembly that the best way to support the value of its proposed 50,000 $£_{\mathrm{PA}}$ emission was to augment the tax-redemption mechanism with annual interest payments. Doing so would eliminate the need for a legal tender law, which was a bone of contention between the proprietor, John Penn, and the colonial assembly. Franklin also advocated annual interest payments for the U.S. paper Continental dollar first issued in mid1775. Interest payments, however, were not enacted in either case (Oberg 1992, v. 29, pp. 354-6; 
Labaree 1967, v. 11, pp. 15-18). ${ }^{15}$

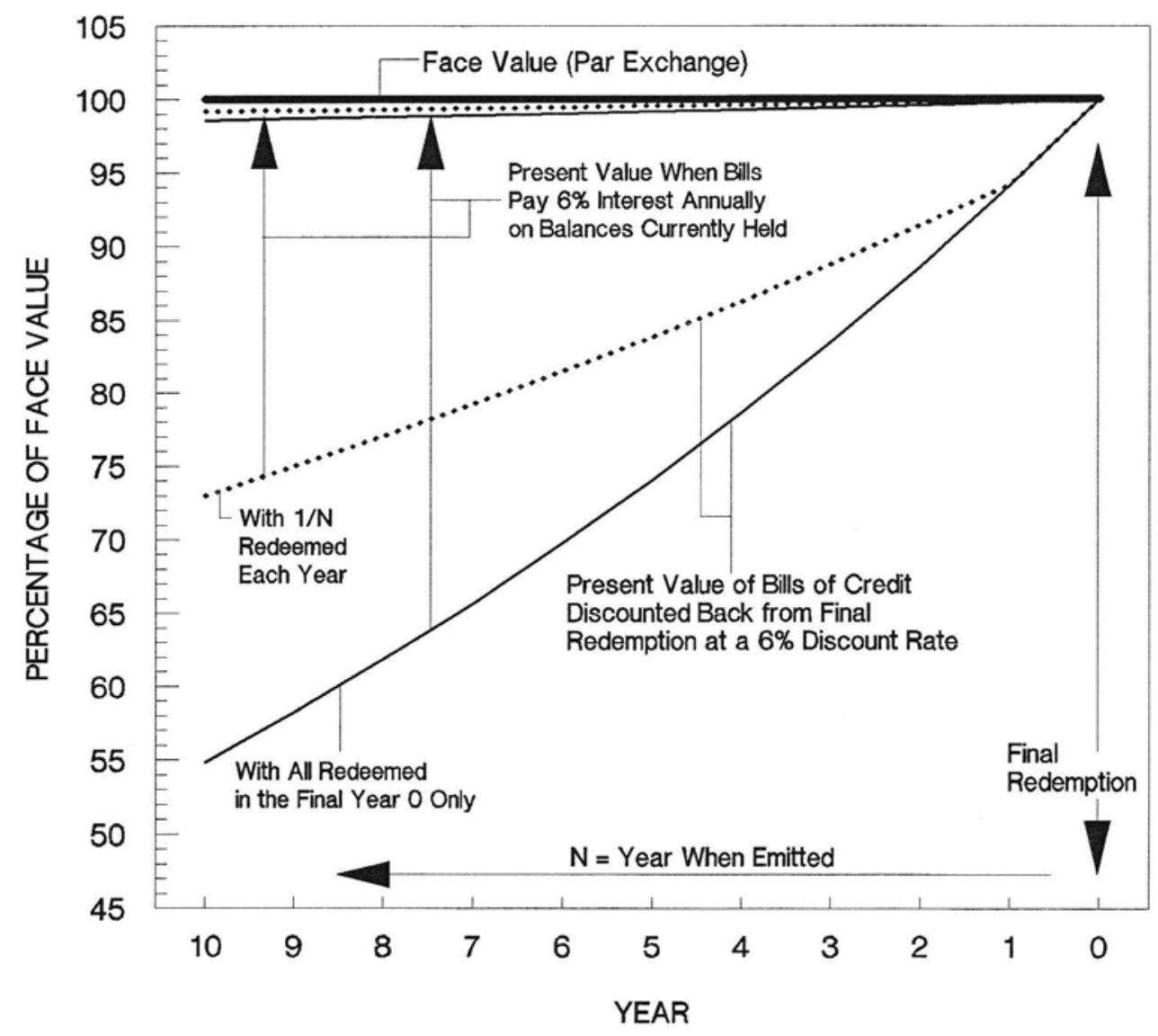

Figure 6. Present Value of Bills of Credit between Emission and Redemption with Annual Interest Paid Equal to the Market Discount Rate

In some cases, paying an annual interest may have been impractical. In the case of the U.S. paper Continental dollar, war prevented the raising of money to pay annual interest. In other cases, it may have generated computational inconveniences, or if the interest paid was higher than the market discount rate, it could lead to the bills being hoarded as investments rather than used as a medium of exchange. In 1767, Franklin commented on the use in New England of bills that bore an annual interest and the problems that arose from using them. He wrote:

Some of the Colonies of New England, who have been many Years restrained from Making Bills a legal Tender, have, in order to keep their Value, and prevent the Inconveniences of a Discount, issued Bills bearing Interest at 5 per Cent. 
In a little Time after they were issued it became worth while to compute the Interest that had accrued on them. Tables were made showing the Interest arising on any Bill of any Sum for a Year, a Month, a Week, and a Day. And yet with all the Help these Tables could afford, it was a perplexing Thing to the common People to make these Computations, and took up Abundance of Time in Shops and Warehouses, to the great Hindrance of Business, there being sometimes in a Payment of Twenty Shillings, four, five, or more Bills of different Denominations, on which the Interest was to be computed.

But the growing Interest had another ill Effect. The Bills were intended for a Currency, and the Interest defeated that Intention. For they were gradually hoarded, and disappear'd long before the Expiration of the Term for which they were omitted: It being a great Convenience to Money'd People to have their Money at Interest, and yet all the while in their Possession, ready for advantageous Purchases if such should offer, which it would not be if out on Mortgages. (Labaree 1970, v. 14, p. 36).

The problem with the interest-bearing bills that Franklin described in New England may have been with how governments paid the interest relative to the frequency with which the bills changed hands - the velocity of circulation (V). ${ }^{16}$ The analysis in Figure 6 assumes that bills could only change hands as a medium of exchange once a year, just after the annual interest was paid to the holder, e.g. $\mathrm{V}=1$. It also assumes that the interest payments could not be deferred, accrued, accumulated, or otherwise attached to a given bill from a multi-year emission-toredemption issuance. Under these two conditions, the problems Franklin listed should not have existed and bills should have always traded at face value as illustrated in Figure 6. However, if either of these two conditions did not hold, then bills would not trade at face value over the relevant transacting interval.

Figure 7 shows what happens if annual interest was allowed to accrue across a multi-year emission-to-redemption issuance and was then paid as an accumulated lump sum to the last holder of the bill at the end of the N-year redemption window (year 0 in Figure 7). The present value of a bill starts substantially below face value at emission and ends substantially above face value at final redemption. Figure 7 uses all the structures and assumptions used in Figures 1 and 6, except that annual interest is only paid as an accumulated lump sum at the end of the $\mathrm{N}$-year 
redemption window.

For example, the text printed on Connecticut bills of credit issued between 1755 and

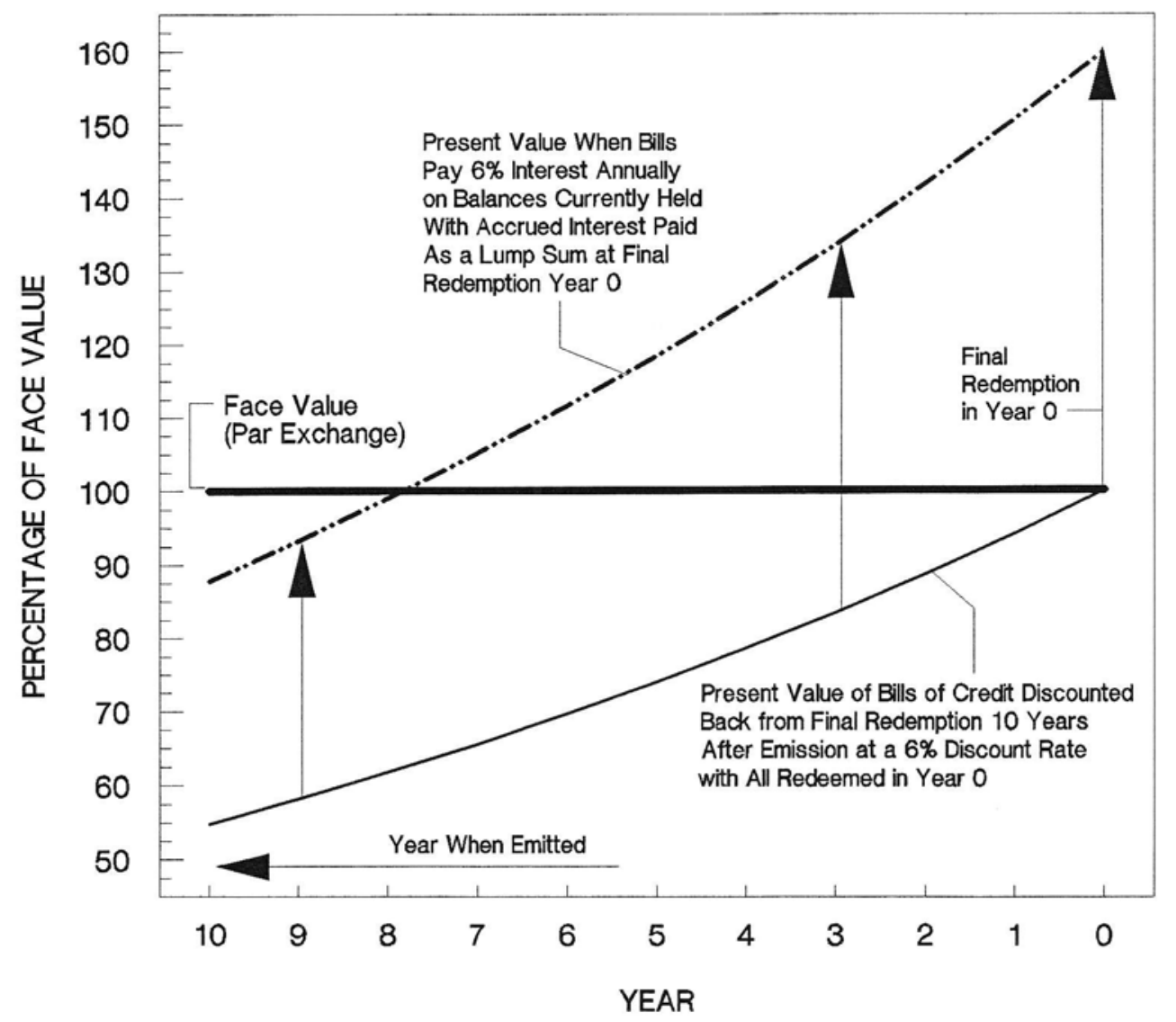

Figure 7. $\quad$ Present Value of Bills of Credit between Emission and Redemption with Annual Interest Paid Equal to the Market Discount Rate But Paid as an Accumulated Lump Sum at the End of the Redemption Window

1770 said, using the text from a 40 shilling bill issued on 26 March 1761, “The possessor of this bill, shall be paid by the Treasurer of the Colony of Connecticut, Forty Shillings Lawful Money, with Interest at Five per Cent, per Annum, by the 26th Day of March, 1766.” This language indicates that the annual interest would be accrued and paid in a lump sum at the end of the redemption period, namely five years of interest accumulated from 1761 to 1766 all paid in a lump sum in 1766 (Newman 2008, p. 103-108). Paying interest in this manner could have led to the speculation in, and the hoarding of, bills that Franklin noted in his observations. 
Figure 8 shows the monthly present value of bills within the annual interest payment interval. Suppose bills pay an annual interest but changed hands more frequently than annually

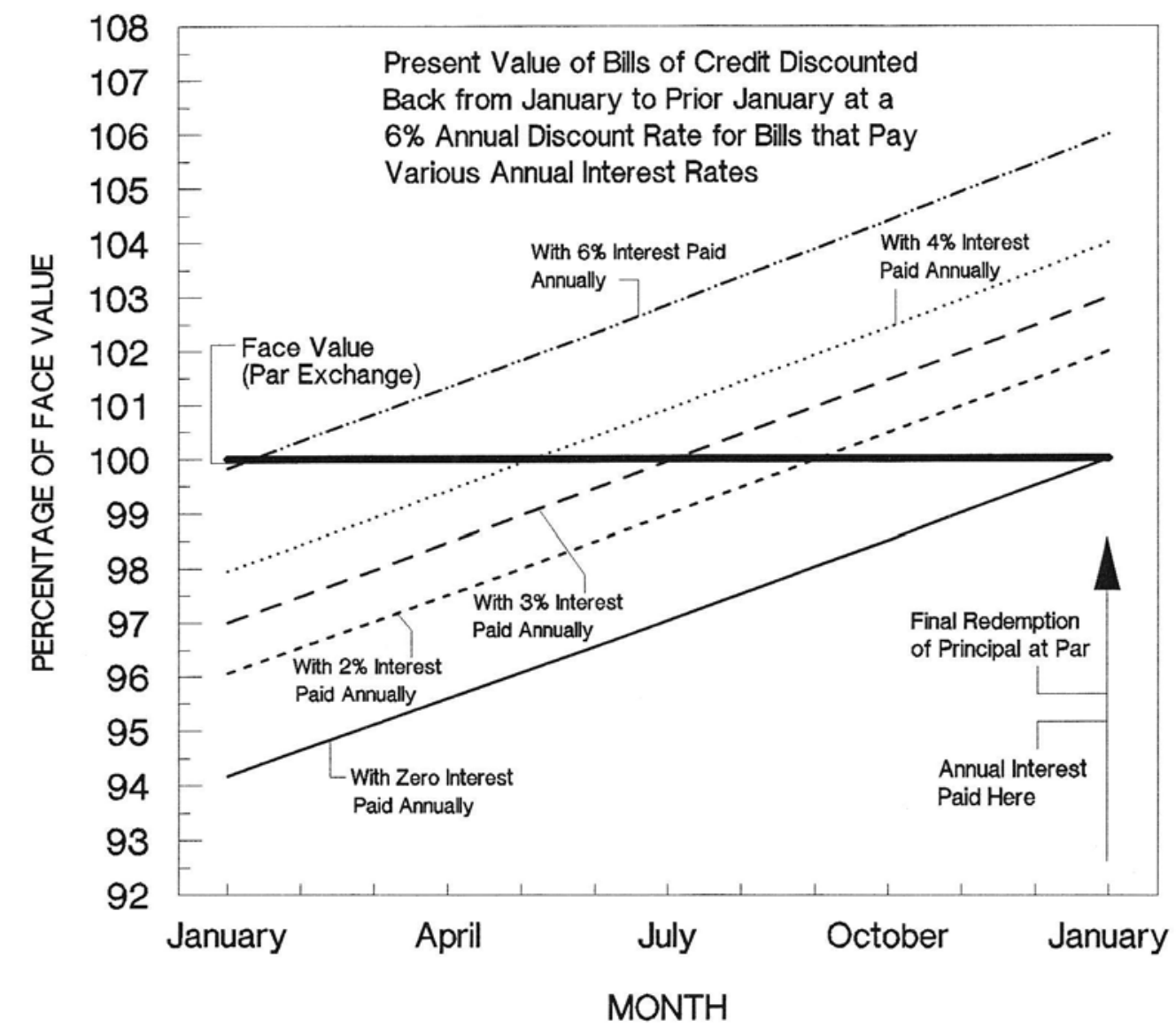

Figure 8. The Present Value of Bills of Credit between Annual Interest Rate Payments

as a medium of exchange, such as monthly. What would the present value of such bills be each month between the annual interest payment points? Figure 8 uses all the structures and assumptions used in Figures 1 and 6, except that it shows what the present value would be with different annual interest rates paid at the end of the year, e.g. a zero, 2, 3, 4, and 6 percent annual interest paid, for the preceding 12 months, namely after the last interest payment but before the next interest payment. As long as the transaction frequency is shorter than the interest payment frequency, the present value of bills will not equal their face value between the interest payment 
intervals. For annual interest rates that are between zero and the market discount rate, the present value of bills will be below face value early in the year and above face value later in the year.

Setting the annual interest rate equal to the discount rate, 6 percent in Figure 8, makes the present value of bills equal to their face value only at the beginning of the year and above their face value thereafter, reaching 6 percent above face value by year's end. After the interest is paid at year's end, the bill's present value drops back to par for the start of the next year, and the cycle repeats. Setting the annual interest rate equal to zero (with final redemption at year's end) makes the present value of the bill start at 6 percent below face value at the beginning of the year, rising steadily until it reaches face value at the end of the year. If bills are issued in one-year emissionto-redemption sequence, then this pattern repeats at the start of the next year.

Between these extremes, an annual interest rate set equal to half the market discount rate, 3 percent in Figure 8, makes a bill's present value equal its face value in the middle of the year, half way between interest payment points. At the beginning of the year it starts at 3 percent below face value. It rises steadily to 3 percent above face value by year's end. After the interest is paid at year's end, the bill's present value drops back to 3 percent below its face value for the start of the next year, and the cycle repeats.

The only way to use interest payments to counterbalance discounting so that bills always trade at face value is to set the interest rate equal to the discount rate, and set the interest payment interval equal to the transaction frequency interval $(\mathrm{V})$. When the transaction frequency is shorter than the interest payment frequency, traders in the marketplace will have to recalculate the present value of each bill used as a medium of exchange to account for when the future holder of the bill will receive an interest payment.

Whether these conditions were actually present in New England and so explain 
Franklin's observations is a topic of future research. Franklin, however, does say that the interest bearing bills issued “...were intended for a Currency...” and that people had to compute the interest accruing on them “...for a Year, a Month, a Week, and a Day.” This suggests that the transaction interval, the frequency with which bills changed hands as a medium of exchange (V), was relatively short, being monthly, weekly or even daily-shorter than the annual interest payment interval. Thus, Figure 8 may illustrate an important constraint in using interest payments to support the value of bills of credit.

The solution to this problem would be to make the interest payment interval equal to the transaction interval. However, the transactions cost of making interest payments to bill holders at very frequent intervals, such as monthly, weekly, or daily, would likely swamp the within-year variation in the present value of the bills when interest was only paid annually. Such high transactions costs may explain why sub-annual interest payments were seldom observed and why supporting bills of credit through paying interest was somewhat rare.

As such, the best that might be achieved using this method would be to choose an annual interest rate near the mid-point between zero and the market discount rate, thus keeping the bills' present value as near face value as possible, plus or minus 3 percent of par in Figure 8 . This last point might explain why some colonies that did pay an annual interest on their bills moved towards a rate less than the prevailing market interest rate over time, e.g. see Connecticut in 1770 and New Hampshire from 1755-63 in Appendix Table A1.

In 1775, when Franklin advocated having the Continental dollar pay an annual interest as a way to support its current value, it may have been because Continental dollars were large denomination bills unfit for general circulation as a currency (Grubb 2013). Franklin may have expected their transaction frequency to be low. As such, Franklin’s apparently shifting views on 
whether bills should pay an interest (yes in 1764, no in 1767, and yes in 1775), may actually be consistent when considering that they were conditional on the expected transaction frequency of the bills relative to the cost-effective frequency over which interest payments could be made.

\section{LEGAL TENDER LAWS}

Many contemporaries, and numerous scholars since, have assumed that legal tender laws supported the circulation and value of bills of credit in colonial America. ${ }^{17}$ Legal tender laws have also been used to justify the assumption that bills of credit were fiat currencies, thus making the existence and analysis of redemption structures irrelevant. These assumptions, however, are erroneous, and were known by contemporaries to be erroneous. Legal tender laws contributed little to the value of the bills. Legal tender laws had their primary effect on creating problems in tort law regarding court-ordered restitution in debt default cases.

Two types of legal tender laws were used in the colonies, a "soft" and a "hard" version, with said laws embedded in the paper money act of each emission. "Soft” legal tender laws simply made it illegal to refuse payment in bills. Its purpose was to force bills into circulation. Only a few cases of soft legal tender laws can be found, e.g. Virginia used soft legal tender laws for its first 5 emissions, but not thereafter (Hening 1969, v. 6, pp. 435-8, 461-8, 521-30; v. 7, pp. 9-33, 46-54, 69-87, 163-9, 171-231, 255-65, 331-7, 347-53, 465-6, 495-502; v. 8, pp. 342-8, 493-503, 647-52; v. 9, pp. 61-71).

Most colonies used "hard” legal tender laws. Hard legal tender laws not only made it illegal to refuse payment in bills, but also fixed the value of the bills so received in payment to be the specie-equivalent of the bills’ face value. Its purpose, besides forcing bills into circulation, was to support the value of bills by making it illegal for them to trade at other than their face value. For examples of hard legal tender laws, see any of New Jersey’s paper money acts (Bush 
1977, pp. 63-6, 68-70, 109-113, 209-213, 301-19, 427-38, 474-87; 1980, pp. 21-8, 307-19, 345-

55, 373-82, 413-25, 455-71, 495-502, 517-29, 539-55, 563-78, 621-39, 663-79; 1982, pp. 73-89,

125-40, 207-21, 289-306).

Legal tender laws per se, whether soft or hard, cannot make paper money trade at its specie-equivalent face value. The evidence in Figure 5 shows that bills traded considerably below their face value in colonies using legal tender laws. In Figure 5, values do not change much from when bills were a legal tender before 1764 to when legal tender laws were prohibited after 1764. The statistical analysis in Table 1 shows that structural breaks in value around 1764 are related to changes in redemption structures and Seven-Year-War finances rather than to the 1764 prohibition on legal tender laws. Why this should be so was articulated by contemporaries.

In 1764, Benjamin Franklin, in the longest speech of his career (among his surviving texts), explained to the Pennsylvania Assembly the fallacy of thinking that legal tender laws per se could support the specie value of their bills of credit (Labaree 1967, v. 11, p. 14),

And indeed of what Force can it [a legal tender law] be to fix an arbitrary Value on the Bills [of Credit], unless the Value of all Things to be purchased by the Bills could be fix'd by the same Law. I want to buy a Suit of Cloth, and am told by the Seller, that his Price is 20s. [20 Shillings] a Yard. Very well, say I, cut me off 5 Yards, and here are five 20s. Bills for you. I beg your Pardon, says he, the 20s. that I mean is 20s. lawful Money, according to such an Act of Parliament: Your Paper Money is greatly depreciated of late; it is of no more than half its nominal Value, your 20s. is really worth but ten; so that if you pay me in those 20s. Bills you must give ten of them for five Pounds. Don't talk so to me, says I, you are oblig'd by Act of Assembly to take these Bills at 20s. each. Very well, says he, if I must take them so I must; but as the Law sets no Price on my Goods, if you pay me with those Bills at 20s. each, my Cloth is 40 s. a Yard, and so you must still give me ten of them; and pray then what becomes of your Law?

In 1767, Franklin also pointed out that in colonies where bills of credit had been made a legal tender, the bills still traded below face value (Labaree 1970, v. 14, p. 35).

In 1776, Adam Smith, in the Wealth of Nations, echoed Franklin's point. Smith stated, "A positive law may render a shilling a legal tender for a guinea; because it may direct the courts 
of justice to discharge the debtor who has made that tender. But no positive law can oblige a person who sells goods, and who is at liberty to sell or not to sell, as he pleases, to accept of a shilling as equivalent to a guinea in the price of them.” (Smith 1937, p. 311).

In 1788, Franklin made a more succinct and clear statement of this principle, "The making of paper [money] with such a sanction [a legal tender law] is.... folly, since, although you may by law oblige a citizen to take it for his goods, you cannot fix his prices; and his liberty of rating them as he pleases, which is the same as setting what value he pleases on your money, defeats your sanction.” (Smyth 1907, v. 9, p. 638).

Suppose I have a good for sale in New Jersey in 1722 that is worth $1 £_{\text {Sterling }}$ and I post its

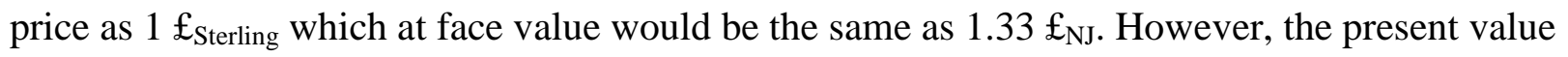
of a $£_{\mathrm{NJ}}$ in 1722 is 80 percent of its face value, see Figure 5. As such, I would set my posted prices for the good to be $1 £_{\text {Sterling }}$ or $1.66 £_{\mathrm{NJ}}$. I would have a two-tier price system that reflected the present value of the bills in the current marketplace relative to their face value. A legal tender law that requires that I accept bills in payment, but does not control prices or exchange rates, i.e. a soft legal tender law, cannot by itself support the value of the bills or push their value toward their specie-equivalent face value.

Now suppose that the legal tender law includes a statement fixing the face value of the bills in specie when used in trade, i.e. a hard legal tender law. Under a hard legal tender law the

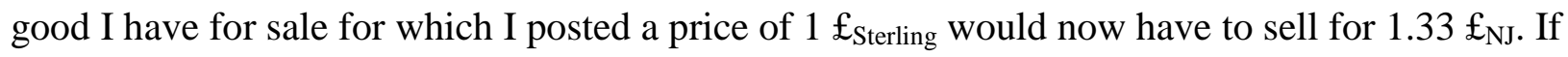
someone offered $1.33 £_{\mathrm{NJ}}$, I could not refuse this offer under a hard legal tender law, even if the present value of a $£_{\mathrm{NJ}}$ was 80 percent of its face value. I want to be paid $1.66 £_{\mathrm{NJ}}$ for the good but I cannot post that price or refuse the offer of $1.33 £_{\mathrm{NJ}}$ if I post the good's price as $1 £_{\text {Sterling. }}$

However, even a hard legal tender law does not support the value of the bills or cause 
them to trade closer to their face value. Figure 5 indicates that subjects must have found a way to nullify the effect of hard legal tender laws. The simplest way to nullify a hard legal tender law was to not post or contract in prices stated in specie or sterling units, but only to post or contract in prices expressed in the monetary units of the bills of credit. For example, for the good I want

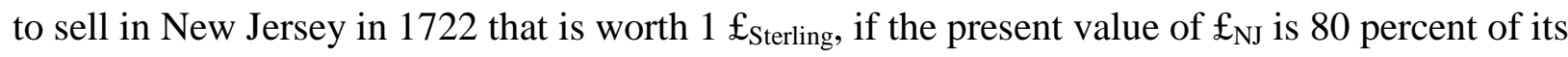
face value, I would be willing to (indifferent to) accepting $1.66 £_{\mathrm{NJ}}$ or $1 £_{\text {Sterling }}$ for the good. If I post the price as $1 £_{\text {Sterling }}$ I may be forced to accept $1.33 £_{\mathrm{NJ}}$ in payment under a hard legal tender law, thus losing money. I cannot post a two-tier price of $1 £_{\text {Sterling }}$ or $1.66 £_{\mathrm{NJ}}$ because having posted a price of $1 £_{\text {Sterling }}$ I could not refuse $1.33 £_{\mathrm{NJ}}$ in payment under a hard legal tender law. The solution, however, is easy. I simply stop posting prices in sterling or specie units. I only post prices in bills-of-credit units of account. I post my price for the good in question to be $1.66 £_{\mathrm{NJ}}$ only. Under a hard legal tender law, $1.66 £_{\mathrm{NJ}}$ is equal to $1.25 £_{\text {Sterling. }}$ But I cannot sell the good for $1.25 £_{\text {Sterling }}$ because that price is above its worth and no one will pay it. The good is actually worth, and I would accept, $1 £_{\text {Sterling }}$ in lieu of $1.66 £_{\mathrm{NJ}}$, but I do not publicly say that. I would take the offer of $1 £_{\text {Sterling }}$ in lieu of $1.66 £_{\mathrm{NJ}}$ but only under-the-table or off-the-record as a

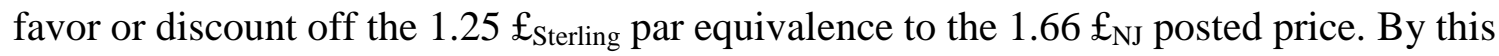
behavior, I have completely nullified the hard legal tender law's effort to support the face value of the bills in trade.

The testable hypothesis implied by this analysis is that when hard legal tender laws are operative pricing in the marketplace should gravitate toward being dominated by pricing in the bills-of-credit monetary unit of account. Pre-1764, ubiquitous usage of each colony’s paper pound unit of account in recorded government transactions, marketplace transactions, newspaper statements, merchant account bookkeeping, and wills is consistent with this behavior nullifying 
the effect of legal tender laws on a bill's value. Conversely, when hard legal tender laws were inoperative, the testable implication is that pricing in the marketplace should be relatively less dominated by pricing in the bills-of-credit monetary unit of account. Preliminary evidence indicates that unit-of-account usage follows these hypothesized patterns (Grubb 2004, 2013).

As such, hard legal tender laws only transform pricing in the marketplace so that it is dominated by the bills-of-credit monetary unit. If a seller happened to price in $£_{\text {Sterling }}$ and was forced by a customer under the auspices of the hard legal tender law to accept paper bills of credit at par value instead of at their present value, the seller would quickly adapt by 1) not pricing in $£_{\text {Sterling }}$ but only in bills-of-credit monetary units, and/or 2) never dealing with that customer again. Faced with this outcome, customers, especially repeat customers, would not force sellers to take bills at par rates but only at their present value. These sellers and customers would privately contract and price in both sterling and bills of credit and consummate such trades at their present value exchange rate without invoking hard legal tender law enforcements.

Hard legal tender laws, however, created potential problems in the application of tort law. They could cause havoc when non-contemporaneous trades suffered contract breach and ended up in court for adjudication. Non-contemporaneous trades are when the payments by one party are at some future date from the initial contract, or the initial delivery of the goods that corresponds to those payments. Breach of contract is when the party who pays last, the debtor or purchaser, reneges on the promised payment to the party who paid first, the creditor or seller. The creditor or plaintiff could then sue the debtor in court seeking to recover the promised payment. When finding in favor of the plaintiff or creditor, courts would make the plaintiff whole by enforcing the payment promised. In cases where the defendant or debtor either could not deliver the specific payment promised, e.g. did not have the specific horse he promised to 
deliver, or the specific specie coins he promised to pay, or where the contractual payment was vague regarding the monetary instrument, such as "16 pounds”, the courts had to assign a monetary substitute that would make the plaintiff whole.

The presence of a legal tender law tied the hands of the courts in these breach of contract cases. The monetary substitute assigned to make the plaintiff whole had to be the designated legal tender. The issue for the courts was whether the legal tender monetary substitute would be priced at its present value (APV), its market value (MEV), or at its face value. If $\mathrm{MEV} \approx \mathrm{APV}$, as argued here, it was really an issue of pricing at present value or at face value. If the courts priced at present value, the plaintiff was indeed made whole and no injustice would be done. Benjamin Franklin claimed that in Pennsylvania this was indeed the case. In 1767, Franklin observed, “...it having ever been a constant rule there [in Pennsylvania] to consider British debts [those in sterling] as payable in Britain, and not to be discharged but by as much paper [money] as would purchase a bill for the full sterling sum.” Franklin goes on to write in a draft petition, “...in the Courts of Justice [in Pennsylvania], full satisfaction has ever been given in discharge of debts due to the British merchant [in sterling valuation]...” In 1760 the British Board of Trade made the same observation. They concluded that Pennsylvania had been exempted from Parliament's 1751 Currency Act that forbid making paper money a legal tender because, “...the province had, without a Law, come of itself very near the regulation which the Law would have prescribed.” (Labaree 1966, v. 9, p. 149; 1970, v. 14, pp. 34-36, 80, 185).

But what if the courts valued bills at their face value when making the plaintiff whole in breach of contract cases? In such cases, the plaintiff would not be made whole, but would be paid less than the sum originally contracted. The size of the underpayment would be the gap between the present value of the bills and their face value, see Figure 5. 
If it were known that courts would use the face value rather than the present value to make plaintiffs whole in breach-of-contract cases, then strategic behavior by debtors and unjust outcomes for creditors would be encouraged. Given that bills had present values well below their face values, debtors would be tempted to breach their contracts knowing that courts would count bills at their face value when ordering restitution. Such suspected behavior in New England in the 1740s, and in Virginia in the late 1750s and early 1760s, may have been behind Parliament's passage of the 1751 and 1764 Currency Acts, respectively.

In 1776, Adam Smith, in the Wealth of Nations, made a similar observation. He said,

The paper currencies of North America consisted...in a government paper, of which the payment was not exigible till several years after it was issued: And though the colony governments paid no interest to the holders of this paper, they declared it to be, and in fact rendered it, a legal tender of payment for full value for which it was issued. But allowing the colony security to be perfectly good, a hundred pounds payable fifteen years hence...in a country where interest is at six per cent. is worth little more than forty pounds ready money. To oblige a creditor...to accept of this as full payment for a debt of a hundred pounds actually paid down in ready money, was an act of such violent injustice, as has scarce...been attempted by the government of any other country which pretended to be free. It bears the evident mark of having originally been...a scheme of fraudulent debtors to cheat their creditors....

No law, therefore could be more equitable than the act of parliament, so unjustly complained of in the colonies, which declared that no paper currency to be emitted there in time coming, should be a legal tender in payment (Smith 1937, pp. 310-11).

Smith's analysis of the initial conditions of colonial paper money regarding discounted valuation is not that different from what Franklin stated in his 1767 paper "The Legal Tender of Paper Money in America” (Labaree 1970, v. 14, pp. 32-39). Their conclusions regarding the effect of legal tender laws on these initial conditions, however, were diametrically opposed. Smith assumed that courts would assign the legal tender substitute at its face value, whereas Franklin pointed out that, at least in the middle colonies, the courts used the present value when assigning a payment substitute in breach-of-contract cases. ${ }^{18}$

So what role did legal tender laws serve? If they did not support the value of paper 
money, and they potentially caused havoc when misapplied by courts in breach-of-contract cases, what good were they? Franklin gives a hint in 1767 when he wrote that the purpose of legal tender laws was “...the convenience to the possessor where every one is oblig'd to take them...” (Labaree 1970, v. 14, p. 34). This would be a “soft” legal tender law outcome. Knowing that bills could be used in any transaction may have enhanced their liquidity premium (LP in equation 1) and so enhanced their market value above their present value. Adding some LP to APV would push MEV toward face value. Preliminary estimate for New Jersey and post-1765 Maryland, however, indicate that legal-tender-law effects on changing LP were negligible, and that LP in general accounted for a small portion of MEV. MEV was primarily made up of APV (Celia and Grubb 2014, Grubb 2014).

From the totality of Franklin's writings on the subject, soft legal tender laws also appear to solve the short-run hold-up problem. Franklin sees specie as being prone to unexpected shortrun fluctuations in availability due to unexpected foreign trade shocks. Bills of credit were not prone to these effects as they had no exportable value. If a creditor who was owed a payment in specie could refuse being paid in an equivalent amount of bills at their present value exchange rate, then the creditor could exert undue short-term leverage over the debtor when specie was unexpectedly scarce. Under these circumstances, creditors could extort more payment than the present value equivalent of specie owed by the debtor by threatening the debtor with prison for non-payment of the specific specie money contracted. Given enough time, the debtor could solve this problem, exchanging bills for specie at the present value rate of exchange. It is the presence of short-run trade disruptions that creates these temporary hold-up extortion opportunities for creditors. Legal tender laws removed this creditor-extortion possibility, e.g. Shylock’s demand for a literal pound of flesh and no equivalent (Shakespeare, Merchant of Venice), by requiring 
the creditor to accept the present-value equivalence in bills.

But why have a hard, as opposed to just a soft, legal tender law? In most cases, hard legal tender laws were how colonial legislatures credibly anchored the value of their paper money to specie at the point of redemption. When a bill was to be redeemed, subjects could always pay in a bill's face value specie equivalence instead. If a subject did not have the bills of credit needed to pay their redemption obligation, they had to be allowed to pay in some other lawful way. The government had to specify the value equivalence between bills and this other lawful payment. It was this alternative payment in sterling or specie that anchored the face value of bills to the par sterling exchange rate at redemption. Hard legal tender laws were simply ways for the colonial government to credibly state and execute this outcome.

Legal tender laws may have served one other positive function. While not fully articulated as argued here, in 1767 Franklin offered the following reason for legal tender laws (Labaree 1970, v. 14, pp. 35-36). Bills of credit required time-discounting to determine their present value. Staggered overlapping emissions could stabilize the average present value of these bills. However, having bills from different emissions with different redemption dates and hence different present values circulating concurrently created a cumbersome medium of exchange. If each bill was priced correctly at its present value, valuation differences among concurrent bills in circulation would raise the transactions cost of using the paper money as a medium of exchange. Hard legal tender laws made the bills fungible when paid to satisfy redemption obligations for the various overlapping emissions. As long as total redemption obligations were equal to or greater than total bills in circulation, it would not matter which bill from which emission was used to satisfy any particular current redemption obligation. This action reduced the present value differences among bills from overlapping emissions currently outstanding. As such, hard 
legal tender laws served to remove confusion over the relative valuation of a colony's bills from different but overlapping emissions that were circulating concurrently.

Why the British passed the 1751 and 1764 Currency Acts makes sense in light of the forgoing analysis. These Acts did not ban paper money. They only restricted its emission-tofinal-redemption span and its legal tender status. These restrictions only make sense if bills of credit were structured as zero-coupon bonds that required time-discounting to assess their $\mathrm{APV}_{\mathrm{t}}$, and hence their $\mathrm{MEV}_{\mathrm{t}}$, and courts did not take this into account in tort law cases. These Acts wanted to lessen the loss to creditors occurring when courts assigned the face value of bills, rather than their $\mathrm{APV}_{\mathrm{t}} \approx \mathrm{MEV}_{\mathrm{t}}$ value, when making a plaintiff whole in breach-of-contract cases. This explains the restriction on the emission-to-final-redemption span in the 1751 Currency Act. A shorter redemption span reduces the gap between the time-discounted APV and the face value, see Figure 1. This restriction, however, could not completely solve this tort law problem as some gap in value between $\mathrm{APV}_{\mathrm{t}}$ and face value would still exist.

The complete solution was to ban using bills as a legal tender. This solved the tort law problem, as restitution in breach-of-contract cases were no longer required to be in bills of credit. However, this solution had costs. These costs included losing the minor benefits discussed above from making bills a legal tender, but more importantly, they increased the cost of adjudicating breach-of-contract cases. How could a plaintiff now be made whole when the debtor did not fulfill the specifics of the contract? With specie money chronically scarce, and no other legal tender, how were courts to rule? The problem of tort law breach-of-contract cases and how to impose restitution was an on-going and paramount problem in colonial America, for examples see the legislative history of colonial New Jersey (Bush 1977, 1980, 1982, 1986).

The tort law problem generated by legal tender laws was contingent on bills of credit 
being structured as zero-coupon bonds. Thus, another solution to the problem would have been to require all bills to pay the market interest rate on their face value. This would have moved a bill's $A P V_{t}$ very close to face value regardless of redemption span or redemption structure, see Figures 6 and 8. Bills could remain a legal tender and courts could assign their face value when deciding restitution in tort cases without hurting creditors. This solution was actually proposed. Ernst (1973, p. 88) reports that in the debates over regulating colonial bills of credit leading to the 1764 Currency Act, Glasgow merchants requested that all colonial bills be required to pay 5 percent interest. This request, however, was not adopted into the Act. This proposal only makes sense if bills of credit were understood to be zero-coupon bonds with variable redemption spans. Why this solution was not adopted is unclear. Perhaps the transaction costs, explained above, of implementing interest-bearing paper money were considered too high.

Why Virginia's behavior was singled out as the cause of the 1764 Currency Act (Ernst 1973), can now be answered. From 1755 through 1756, Virginia issued bills with short redemption windows and tightly staggered overlapping emissions. The APV of these bills would be close to face value, i.e. following a Figure 2 pattern. After 1756, Virginia shifted to longish redemption windows with tightly staggered overlapping emissions, and from soft to hard legal tender laws. The 1757 to 1762 value pattern was between those shown in Figures 3 and 4, see Figure 5 and Appendix Table A1.

This shift in emission-redemption structure and legal tender laws created stress for British creditors in the Virginia market. Any merchant who contract in Virginia pounds in 1755-6 found that the present value of average Virginia bills had fallen 20 percentage points by 1762 . If courts enforced the restitution of contract debt claims from the mid-1750s in post-1760 bills, using as justification the new hard legal tender laws embedded in Virginia's more recent paper money 
acts, British creditors could lose a lot. Prohibiting legal tender laws stopped this potential loss. The rebound in the value of Virginia bills after 1768, however, was not due to the 1764 Currency Act. This rebound was simply the result of shifting to a Figure 2 redemption structure after 1768, see Figure 5 and Appendix Table A1. The 1764 Currency Act simply solved the tort law problem of courts improperly counting bills at face value rather than at their present value. It did not directly impact or improve the value of Virginia bills.

In conclusion, colonial assemblies did not set out intentionally to defraud people with paper money and legal tender laws. It was how courts interpreted legal tender laws and the face value exchange rate to sterling when applying such laws to breach-of-contract cases that could lead potentially to creditors being defrauded. Laws designating bills of credit, structured as zerocoupon bonds, a legal tender primarily created problems only in the adjudication of tort law cases and had little bearing on fixing the trade value of colonial paper money. Colonial legislatures insisted on hard legal tender laws simply as convenient devices to anchor the value of their bills at the point of maturity and so provide credibility to the government's redemption exercise.

\section{CONCLUSIONS}

This essay explores an alternative view of colonial paper money. In summary, colonial legislatures put considerable effort into designing monetary structures. Taking that effort seriously implies that paper money was not just paper money, i.e. it was not just fiat currency. Instead, paper bills were either zero-coupon bonds or interest-bearing bonds. Their present values were contingent on their redemption structures, interest payments, and the market discount rates. These contingencies varied across emissions. Thus, the face value of paper bills cannot be compared over time or summed across emissions for analytical purposes. This 
observation renders most past economic studies of colonial paper monies meaningless. In addition, this observation indicates that paper bills traded below face value due to timediscounting not depreciation. Scholars both past and present have simply confused timediscounting for depreciation. The market value of paper bills was primarily determined by their asset present values. Legal tender laws only affected tort law outcomes.

The preliminary findings here indicate that this research approach holds promise. The next stages involve the painstaking and time-consuming effort to establish the actual redemption structures as executed for each paper money emission, to construct the exact time-series of representative bills’ present values, and relate those values to the respective paper money’s market value. This has only been done so far for colonial New Jersey (Grubb 2014, 2015).

With independence, British restrictions on bank corporations were removed and the U.S. shifted toward creating an inside paper money out of banknotes that were fractionally backed by specie reserves (outside money), with banknotes exchangeable for specie at face value on demand at the issuing bank. Despite the instability of fractional reserve banking systems, banknotes were a superior paper money because their market value would always be very close to their face value (barring a liquidity crisis). This was a feature that colonial bills of credit structured as zero-coupon bonds could not achieve. 


\section{References}

Archives of Maryland, Vol. 1-72. Baltimore: Maryland Historical Society, 1883-1972.

Barlow, J. J. (ed.) 2012. To Secure the Blessings of Liberty: Selected Writings of Gouverneur Morris. Indianapolis, IN: Liberty Fund.

Bordo, M. D. 1987. Equation of exchange. In The New Palgrave: A Dictionary of Economics. Vol. 2, edited by J. Eatwell, M. Milgate, and P. Newman, 175-7. London: Macmillan.

Brock, L. V. 1975. The Currency of the American Colonies, 1700-1764. New York: Arno.

Brock, L. V. 1992. The colonial currency, prices, and exchange rates. Essays in History 34, 70-132 [posthumously published].

Bullock, C. J. 1897. Introduction: life and writings of William Douglass. Economic Studies 2, 265-91.

Bullock, C. J. 1900. Essays on the Monetary History of the United States. New York: Macmillan.

Bush, B. (ed.) 1977. Laws of the Royal Colony of New Jersey, 1703-1745. Trenton, NJ: New Jersey State Library, Archives and History Bureau.

Bush, B. (ed.) 1980. Laws of the Royal Colony of New Jersey, 1746-1760. Trenton, NJ: New Jersey State Library, Archives and History Bureau.

Bush, B. (ed.) 1982. Laws of the Royal Colony of New Jersey, 1760-1769. Trenton, NJ: New Jersey State Library, Archives and History Bureau.

Bush, B. (ed.) 1986. Laws of the Royal Colony of New Jersey, 1770-1775. Trenton, NJ: New Jersey Division of Archives and Records Management.

Carter, S. B., et al. (eds.) 2006. Historical Statistics of the United States Earliest Times to the Present Millennial Edition, Volume 5. New York: Cambridge University Press.

Catanzariti, J., Nuxoll, E. M., Gallagher, M. A., et al., eds. 1988. The Papers of Robert Morris, 1781-1784, Vol. 7. Pittsburgh, PA: University of Pittsburgh Press.

Celia, J. and Grubb, F. 2014. Non-legal-tender paper money: the structure and performance of Maryland's bills of credit, 1767-1775. National Bureau of Economic Research Working Paper 20524.

Colonial Laws of New York from the Year 1664 to the Revolution, Vols. 1-5. 2011. Clark, NJ: The Lawbook Exchange, LTD. [original 1894]. 
Davis, A. M. 1964. Colonial Currency Reprints, 1682-1751, Vols. 3-4. New York: Augustus M. Kelly.

Elliot, J. 1843. Funding system of the United States and Great Britain. House of Representatives Document No. 15 (Vol. II. Executive Documents), $28^{\text {th }}$ Congress, $1^{\text {st }}$ Session, Read on Dec. 16, 1843. [Reprinted New York: Burt Franklin, 1971].

Enders, W. 1995. Applied Econometric Time Series. New York: John Wiley.

Ernst, J. E. 1973. Money and Politics in America, 1755-1775. Chapel Hill, NC: University of North Carolina Press.

Fisher, I. 1912. The Purchasing Power of Money. New York: Macmillan.

Goldberg, D. 2009. The Massachusetts paper money of 1690. Journal of Economic History 69, 1092-106.

Greene, J. P. 1980. The Seven Years' War and the American Revolution: the causal relationship reconsidered. In The British Atlantic Empire before the American Revolution edited by P. Marshall and G. Williams, 85-105. London: Frank Cass.

Greene, J. P. and Jellison, R. M. 1961. 'The currency act of 1764 in imperial-colonial relations, 1764-1776. The William and Mary Quarterly 18, 485-518.

Grubb, F. 2003. Creating the U.S.-dollar currency union, 1748-1811: a quest for monetary stability or a usurpation of state sovereignty for personal gain? American Economic Review 93, 1778-98.

Grubb, F. 2004. The circulating medium of exchange in colonial Pennsylvania, 1729-1775: new estimates of monetary composition, performance, and economic growth. Explorations in Economic History 41, 329-60.

Grubb, F. 2008. Creating Maryland's paper money economy, 1720-1739: the role of power, print, and markets. National Bureau of Economic Research Working Paper 13974.

Grubb, F. 2010. Testing for the economic impact of the U.S. Constitution: purchasing power parity across the colonies versus across the states, 1748-1811. Journal of Economic History 70, 118-145.

Grubb, F. 2012. Chronic specie scarcity and efficient barter: the problem of maintaining an outside money supply in British colonial America. National Bureau of Economic Research Working Paper 18099.

Grubb, F. 2013. The Continental dollar: how the American Revolution was financed with paper money —initial design and ideal performance. National Bureau of Economic Research Working Paper 19577. 
Grubb, F. 2014. A new approach to solving the colonial monetary puzzle: evidence from New Jersey, 1709-1775. National Bureau of Economic Research Working Paper 19903.

Grubb, F. 2015. Colonial New Jersey’s paper money regime, 1709-1775: a forensic accounting reconstruction of the data. Historical Methods 48, 13-34.

Hammond, B. 1957. Banks and Politics in America from the Revolution to the Civil War. Princeton, NJ: Princeton University Press.

Hanson, J. R. II. 1979. Money in the colonial American economy: an extension. Economic Inquiry 17, 281-286.

Harris, R. 1994. The Bubble Act: its passage and its effect on business organization. Journal of Economic History 54, 610-627.

Hening, W. W. (ed.) 1969. The Statutes at Large; being a Collection of all the Laws of Virginia, from the First Session of the Legislature, in the Year 1619, Vols. 6-9. Charlottesville, VA: University Press of Virginia [original: Richmond, VA: Franklin Press, 1819-1821].

Homer, S. and Sylla, R. 1991. A History of Interest Rates. New Brunswick, NJ: Rutgers University Press, third edition.

Hutchinson, W. T. and Rachal, W. M. E. (eds.) 1962. The Papers of James Madison, Vol. 1. Chicago: University of Chicago Press.

Journals of the Continental Congress, 1774-1789, Vols. 1-34. 1904-1937. Washington D.C.: Government Printing Office.

Labaree, L. W. (ed.) 1959-1970. The Papers of Benjamin Franklin, Vols. 1-14. New Haven, CT: Yale University Press.

Mark, N. C. 2001. International Macroeconomics and Finance: Theory and Econometric Methods. Malden, MA: Blackwell.

McCallum, B. T. 1992. Money and prices in colonial America: a new test of competing theories. Journal of Political Economy 100, 143-161.

McCusker, J. J. 1978. Money and Exchange in Europe and America, 1600-1775. Chapel Hill, NC: University of North Carolina Press.

Michener, R. W. 1987. Fixed exchange rates and the quantity theory in colonial America. Carnegie-Rochester Conference Series on Public Policy 27, 233-308.

Michener, R. W. 1988. Backing theories and currencies of eighteenth-century America: a comment. Journal of Economic History 48, 682-692. 
Michener, R. W. and Wright, R. E. 2005. State “currencies” and the transition to the U.S. dollar: clarifying some conclusions. American Economic Review 95, 682-703.

Michener, R. W. and Wright, R. E. 2006. Farley Grubb's noisy evasions on colonial money: a rejoinder. Econ Journal Watch 3, 251-274.

Nettels, C. P. 1934. The Money Supply of the American Colonies before 1720. Madison, WI: University of Wisconsin Press.

Newman, E. P. 2008. The Early Paper Money of America. Iola, WI: Krause Publications, ( $^{\text {th }}$ edition).

Newell, M. E. 1998. From Dependency to Independence: Economic Revolution in Colonial New England. Ithaca, NY: Cornell University Press.

Oberg, B. B. (ed.) 1992-1998. The Papers of Benjamin Franklin, vols. 29-34. New Haven, CT: Yale University Press.

Officer, L. H. 2005. The quantity theory in New England, 1703-1749: new data to analyze an old question. Explorations in Economic History 42, 101-21.

Perkins, E. J. 1988. The Economy of Colonial America. New York: Columbia University Press, $2^{\text {nd }}$ edition.

Priest, C. 2001. Currency policies and legal development in colonial New England. Yale Law Journal 110, 1303-1405.

Rabushka, A. 2008. Taxation in Colonial America. Princeton, NJ: Princeton University Press.

Ricord, F. W., ed. 1892. Documents Relating to the Colonial History of the State of New Jersey, Vol. 17. Trenton, NJ: John L. Murphy.

Rodney, R. S. 1928. Colonial Finances in Delaware. Wilmington, DE: Wilmington Trust Company.

Rotwein, E. (ed.) 1970. David Hume Writing on Economics. Madison, WI: University of Wisconsin Press.

Rousseau, P. L. 2006. A common currency: early US monetary policy and the transition to the dollar. Financial History Review 13, 97-122.

Rousseau, P. L. 2007. Backing, the quantity theory, and the transition to the U.S. dollar, 1723-1850. American Economics Review 97, 266-270.

Rousseau, P. L., and C. Stroup. 2011. Monetization and growth in colonial New England, 
1703-1749. Explorations in Economic History 48, 600-613.

Shubik, M. 1987. Fiat money. In The New Palgrave: A Dictionary of Economics. Vol. 2, edited by J. Eatwell, M. Milgate, and P. Newman, 316-317. London: Macmillan.

Smith, A. 1937. The Wealth of Nations. New York: Modern Library.

Smith, B. 1985a. American colonial monetary regimes: the failure of the quantity theory and some evidence in favor of an alternative view. Canadian Journal of Economics 18, 531-565.

Smith, B. 1985b. Some colonial evidence on two theories of money: Maryland and the Carolinas. Journal of Political Economy 93, 1178-1211.

Smith, B. D. 1988. The relationship between money and prices: some historical evidence reconsidered. Quarterly Review, Federal Reserve Bank of Minneapolis 12, 18-32.

Smith, P. H. 1976-1994. Letters of Delegates to Congress, 1774-1789, Vols. 1-21. Washington, DC: Library of Congress.

Smyth, A. H. 1907. The Writings of Benjamin Franklin, Vol. 9. London: Macmillan.

Stark, W. 1952. Jeremy Bentham's Economic Writings, Vol. 2. London: George Allen \& Unwin.

Statutes at Large of Pennsylvania, Vols. 1-17. 1896-. Harrisburg, PA: Clarence M. Busch, State Printer of Pennsylvania.

Sumner, S. 1993. Colonial currency and the quantity theory of money: a critique of Smith's interpretation. Journal of Economic History 53, 139-145.

Thayer, T. 1953. The land-bank system in the American colonies. Journal of Economic History 13, 145-159.

West, R. C. 1978. Money in the colonial American economy. Economic Inquiry 16, 1-15.

Wicker, E. 1985. Colonial monetary standards contrasted: evidence from the Seven Years' War. Journal of Economic History 45, 869-84. 


\begin{tabular}{|c|c|c|c|c|c|c|c|c|c|}
\hline $\begin{array}{l}\text { Colony/ } \\
\text { State }\end{array}$ & $\begin{array}{l}\text { Date } \\
\text { Printed } \\
\text { on the } \\
\text { Bill: } \\
\text { Year } \\
\text { Month } \\
\text { Day }\end{array}$ & $\begin{array}{l}\text { Face } \\
\text { Value of } \\
\text { Amounts } \\
\text { Authorized } \\
\text { to be } \\
\text { Emitted }\end{array}$ & $\begin{array}{c}\text { Annual } \\
\text { Interest } \\
\text { Rate } \\
\text { Paid } \\
(\%)\end{array}$ & \multicolumn{2}{|c|}{$\begin{array}{l}\text { Maximum } \\
\text { Initial } \\
\text { Issuance- } \\
\text { to-Final } \\
\text { Redemption }\end{array}$} & $\begin{array}{l}\mid \\
\mid \text { Emis- } \\
\text { | sion } \\
\text { Date }\end{array}$ & $\begin{array}{l}\text { Re- } \\
\text { demp- } \\
\text { tion } \\
\text { Date }\end{array}$ & $\begin{array}{l}\text { In- } \\
\text { terest } \\
\text { Rate }\end{array}$ & $\begin{array}{l}\text { ted on the Bills: } \\
\text { In addition to the } \\
\text { numerical face value- } \\
\text { what that value was } \\
\text { redeemable or valued in, } \\
\text { or how it was redeemable } \\
\text { or valued }\end{array}$ \\
\hline \multicolumn{10}{|c|}{ New England Colonies/States } \\
\hline \multicolumn{10}{|c|}{ Massachusetts } \\
\hline 1690 & Dec. 10 & $7,000 £$ & 0.0 & ----- & yes $^{\mathrm{b}}$ & yes & no & no & any "stock" in the treasury \\
\hline 1691 & Feb. 3 & $42,000 £$ & $5.0^{\mathrm{C}}$ & ----- & yes & yes & no & no & any "stock" in the treasury \\
\hline 1702 & Nov. 21 & $10,000 £$ & 0.0 & ----- & yes & yes & no & no & any "stock" in the treasury \\
\hline 1708 & Nov. 21 & $40,000 £$ & 0.0 & ----- & yes & yes & no & no & any "stock" in the treasury \\
\hline 1710 & May 31 & $35,000 £$ & 0.0 & ----- & yes & yes & no & no & any "stock" in the treasury \\
\hline 1711 & July 6 & $40,000 £$ & 0.0 & ----- & yes & yes & no & no & any "stock" in the treasury \\
\hline 1713 & Oct. 14 & $10,000 £$ & 0.0 & ----- & yes & ----- & ----- & ----- & ----- \\
\hline \multicolumn{2}{|c|}{$(1714-1740)$} & $958,477 £^{\mathrm{a}}$ & 0.0 & $5-10.00$ & yes & yes & no & no & any "stock" in the treasury \\
\hline \multirow[t]{2}{*}{1737} & Feb. 4 & $36,000 £$ & 0.0 & ----- & yes & yes & no & no & any "stock" in the treasury \\
\hline & July 7 & $2,625 £$ & 0.0 & ----- & yes & yes & no & no & specie \\
\hline 1741 & Jan. 15 & $30,000 £$ & 0.0 & ----- & yes & yes & no & no & (valued in) specie \\
\hline 1742 & July 1 & $15,000 £$ & 0.0 & ----- & yes & yes & no & no & (valued in) specie \\
\hline \multirow[t]{2}{*}{1743} & Jan. 12 & $12,000 £$ & 0.0 & ----- & yes & yes & no & no & (valued in) specie \\
\hline & Nov. 12 & $12,000 £$ & 0.0 & ----- & yes & yes & no & no & (valued in) specie \\
\hline \multicolumn{2}{|c|}{$(1744-1750)$} & $666,837 £$ & 0.0 & ----- & yes & yes & no & no & (valued in) specie \\
\hline 1750 & Jan. 27 & $3,000 £$ & 0.0 & ----- & yes & yes & no & no & (valued in) lawful money \\
\hline \multicolumn{10}{|c|}{ [1751 Currency Act Which Applied only to New England] } \\
\hline 1750 & & $18,400 £$ & 6.0 & $2-3.00$ & no & ----- & ----- & ----- & ----- \\
\hline 1751 & & $9,000 £$ & 6.0 & $2-3.00$ & no & ----- & ----- & ----- & ----- \\
\hline 1752 & & $18,614 £$ & 6.0 & $2-3.00$ & no & ----- & ----- & ----- & ----- \\
\hline 1753 & & $956 £$ & 6.0 & $2-3.00$ & no & ----- & ----- & ----- & ----- \\
\hline 1754 & & $9,332 £$ & 6.0 & $2-3.00$ & no & ----- & ----- & ----- & ----- \\
\hline 1755 & & $36,508 £$ & 6.0 & $2-3.00$ & no & ----- & ----- & ----- & ----- \\
\hline 1756 & & $121,194 £$ & 6.0 & $2-3.00$ & no & ----- & ----- & ----- & ----- \\
\hline 1757 & & $94,181 £$ & 6.0 & $2-3.00$ & no & ----- & ----- & ----- & ----- \\
\hline 1758 & & $118,644 £$ & 6.0 & $2-3.00$ & no & ----- & ----- & ----- & ----- \\
\hline 1759 & & $150,106 £$ & 6.0 & $2-3.00$ & no & ----- & ----- & ----- & ----- \\
\hline 1760 & & $211,346 £$ & 6.0 & $2-3.00$ & no & ----- & ----- & ----- & ----- \\
\hline 1761 & & $210,597 £$ & 6.0 & $2-3.00$ & no & ----- & ----- & ----- & ----- \\
\hline 1762 & & $209,866 £$ & 6.0 & $2-3.00$ & no & ----- & ----- & ----- & ----- \\
\hline 1763 & & $124,873 £$ & 6.0 & $2-3.00$ & no & ----- & ----- & ----- & ----- \\
\hline 1764 & & $72,334 £$ & 6.0 & $2-3.00$ & no & ----- & ----- & ----- & ----- \\
\hline 1765 & & $131,063 £$ & 6.0 & $2-3.00$ & no & ----- & ----- & ----- & ----- \\
\hline 1766 & & $12,385 £$ & 6.0 & $2-3.00$ & no & ----- & ----- & ----- & ----- \\
\hline 1767 & & $197,000 £$ & 6.0 & $2-3.00$ & no & ----- & ----- & ----- & ----- \\
\hline 1768 & & $157,000 £$ & 6.0 & $2-3.00$ & no & ----- & ----- & ----- & ----- \\
\hline 1769 & & $125,850 £$ & 6.0 & $2-3.00$ & no & ----- & ----- & ----- & ----- \\
\hline 1770 & & $100,000 £$ & 6.0 & $2-3.00$ & no & ----- & ----- & ----- & ----- \\
\hline 1771 & & $88,158 £$ & 6.0 & $2-3.00$ & no & ----- & ----- & ----- & ----- \\
\hline 1772 & & $75,091 £$ & 6.0 & $2-3.00$ & no & ----- & ----- & ----- & ----- \\
\hline 1773 & & $909 £$ & 6.0 & $2-3.00$ & no & ----- & ----- & ----- & ----- \\
\hline 1774 & & $16,000 £$ & 6.0 & $2-3.00$ & no & ----- & ----- & ----- & ----- \\
\hline
\end{tabular}




\begin{tabular}{|c|c|c|c|c|c|c|c|c|c|c|}
\hline 1709 & July 1 & & $24,000 £$ & $5.0^{\mathrm{C}}$ & ----- & no & yes & no & no & any "stock" in the treasury \\
\hline 1709 & July 1 & 12 & $10,000 £$ & 0.0 & ----- & no & yes & no & no & any "stock" in the treasury \\
\hline 1713 & May & & $20,000 £$ & 0.0 & ----- & no & yes & no & no & any "stock" in the treasury \\
\hline 1713 & May & & $10,000 £$ & 0.0 & ----- & yes & yes & no & no & any "stock" in the treasury \\
\hline 1724 & Dec. & 1 & $2,000 £$ & 0.0 & ----- & yes & yes & no & no & any "stock" in the treasury \\
\hline 1728 & Oct. & & $4,000 £$ & 0.0 & ----- & yes & yes & no & no & any 'stock' in the treasury \\
\hline 1733 & July & 10 & $30,000 £^{\mathrm{a}}$ & 0.0 & 7.79 & yes & yes & no & no & any "stock" in the treasury \\
\hline 1740 & May & 8 & $30,000 £^{\mathrm{a}}$ & 0.0 & ----- & yes & yes & no & no & (valued in) specie \\
\hline 1740 & July & 8 & $10,000 £$ & 0.0 & ---- & yes & yes & no & no & any "stock" in the treasury \\
\hline 1744 & May 1 & 10 & $4,000 £$ & 0.0 & ----- & yes & yes & no & no & (valued in) specie \\
\hline 1744 & Oct. & 11 & $15,000 £$ & 0.0 & ---- & yes & yes & no & no & (valued in) specie \\
\hline 1745 & Mar. & 14 & $40,000 £$ & 0.0 & ----- & yes & yes & no & no & (valued in) specie \\
\hline 1746 & May & 8 & $3,000 £$ & 0.0 & ----- & yes & yes & no & no & any "stock" in the treasury \\
\hline 1746 & May & 8 & $55,000 £$ & 0.0 & ----- & yes & yes & no & no & (valued in) specie \\
\hline \multicolumn{11}{|c|}{751 Currency Act Which Applied only to New England] } \\
\hline 1755 & Jan. & 8 & $7,500 £$ & 5.0 & 3.00 & no & yes & yes & yes & lawful money \\
\hline 1755 & Mar. & 13 & $12,500 £$ & 5.0 & 4.17 & no & yes & yes & yes & lawful money \\
\hline 1755 & Aug. : & 27 & $30,000 £$ & 5.0 & 5.00 & no & yes & yes & yes & lawful money \\
\hline 1755 & Oct. & 9 & $12,000 £$ & 5.0 & 4.50 & no & yes & yes & yes & lawful money \\
\hline 1758 & Mar. & 8 & $30,000 £$ & 5.0 & 4.17 & no & yes & yes & yes & lawful money \\
\hline 1759 & Feb. & 7 & $20,000 £$ & 5.0 & 4.25 & no & yes & yes & yes & lawful money \\
\hline 1759 & Mar. & 8 & $40,000 £$ & 5.0 & 5.00 & no & yes & yes & yes & lawful money \\
\hline 1759 & May & 10 & $20,000 £$ & 5.0 & 4.00 & no & yes & yes & yes & lawful money \\
\hline 1760 & Mar. & 13 & $70,000 £$ & 5.0 & 5.00 & no & yes & yes & yes & lawful money \\
\hline 1761 & Mar. & 26 & $45,000 £$ & 5.0 & 5.00 & no & yes & yes & yes & lawful money \\
\hline 1762 & Mar. & 4 & $65,000 £$ & 5.0 & 5.00 & no & yes & yes & yes & lawful money \\
\hline 1763 & Mar. & 12 & $10,000 £$ & 5.0 & 2.00 & no & yes & yes & yes & lawful money \\
\hline 1764 & Mar. & 8 & $7,000 £$ & 5.0 & 3.00 & no & yes & yes & yes & lawful money \\
\hline 1770 & May & 10 & $10,000 £$ & 2.5 & 2.00 & no & yes & yes & yes & lawful money \\
\hline 1771 & Oct. & 10 & $12,000 £$ & 0.0 & 2.00 & no & yes & yes & no & lawful money \\
\hline 1773 & June & 1 & $12,000 £$ & 0.0 & 2.00 & no & yes & yes & no & lawful money \\
\hline \multicolumn{11}{|c|}{ New Hampshire } \\
\hline 1709 & Dec. & 6 & $8,000 £$ & 5.0 & 5.00 & no & yes & no & no & any "stock" in the treasury \\
\hline 1710 & Dec. & 2 & $2,500 £$ & 5.0 & ----- & no & yes & no & no & any "stock" in the treasury \\
\hline 1711 & May & 14 & $1,000 £$ & 0.0 & ----- & no & yes & no & no & any "stock" in the treasury \\
\hline 1711 & Oct. & 10 & $2,000 £$ & 0.0 & ----- & no & yes & no & no & any "stock" in the treasury \\
\hline 1712 & Oct. & 15 & $500 £$ & 0.0 & ----- & no & yes & no & no & any "stock" in the treasury \\
\hline 1714 & May & 14 & $1,200 £$ & 0.0 & ----- & no & yes & no & no & any "stock" in the treasury \\
\hline 1717 & May 2 & 20 & $15,000 £^{a}$ & 0.0 & 11.00 & no & yes & no & no & any "stock" in the treasury \\
\hline 1722 & & & $4,800 £$ & 0.0 & ----- & no & yes & no & no & any "stock" in the treasury \\
\hline$(1724$ & -1729) & & $9,700 £$ & 0.0 & 13.00 & no & yes & no & no & any "stock" in the treasury \\
\hline 1737 & Apr. & 1 & $7,900 £$ & 0.0 & 5.00 & no & yes & no & no & any "stock" in the treasury \\
\hline 1740 & Aug. & 7 & $2,700 £$ & 0.0 & 2.00 & no & yes & no & no & any "stock" in the treasury \\
\hline 1742 & Apr. & 3 & $6,000 £$ & 0.0 & ---- & yes & yes & no & no & (valued in) specie \\
\hline 1743 & June & 2 & $25,000 £^{\mathrm{a}}$ & 0.0 & ----- & yes & yes & no & no & (valued in) specie \\
\hline 1745 & Feb. 1 & 16 & $87,000 £$ & 0.0 & 21.00 & yes & yes & no & no & (valued in) specie \\
\hline \multicolumn{11}{|c|}{ [1751 Currency Act Which Applied only to New England] } \\
\hline 1755 & Apr. & 3 & $30,000 £$ & 1.0 & 5.75 & no & yes & no & yes & (valued in) specie \\
\hline 1756 & Jan. & 1 & $15,000 £$ & 1.0 & 5.00 & no & yes & no & yes & (valued in) specie \\
\hline 1756 & June & 1 & $70,500 £$ & 1.0 & 6.50 & no & yes & no & yes & (valued in) specie \\
\hline 1759 & & & $13,000 £$ & 2.5 & 3.00 & no & yes & no & yes & Sterling bills of exchange \\
\hline 1760 & Mar. & 1 & $8,000 £$ & 2.5 & 4.75 & no & yes & yes & yes & Sterling bills of exchange \\
\hline 1761 & Jan. & 1 & $7,000 £$ & 2.5 & 5.00 & no & yes & yes & yes & Sterling bills of exchange \\
\hline 1761 & May & 1 & $12,000 £$ & 2.5 & 4.67 & no & yes & yes & yes & Sterling bills of exchange \\
\hline 1762 & Jan. & 1 & $8,000 £$ & 2.5 & 5.00 & no & yes & yes & yes & specie \\
\hline
\end{tabular}




\begin{tabular}{|c|c|c|c|c|c|c|c|c|c|}
\hline 1762 & July 1 & $10,000 £$ & 2.5 & 5.00 & no & yes & yes & yes & specie \\
\hline 1763 & Jan. 1 & $10,000 £$ & 2.5 & 5.00 & no & yes & yes & yes & specie \\
\hline \multicolumn{10}{|c|}{ Rhode Island } \\
\hline 1710 & Aug. 16 & $13,300 £$ & 0.0 & 5.00 & yes & yes & no & no & any "stock" in the treasury \\
\hline 1715 & July 5 & $40,000 \varepsilon^{\mathrm{a}}$ & 0.0 & 10.00 & no & yes & no & no & any "stock" in the treasury \\
\hline 1721 & & $40,000 \varepsilon^{\mathrm{a}}$ & 0.0 & 5.00 & no & yes & no & no & any "stock" in the treasury \\
\hline 1724 & & $2,000 £$ & 0.0 & ----- & no & yes & no & no & any "stock" in the treasury \\
\hline 1728 & & $49,000 £^{\mathrm{a}}$ & 0.0 & 20.00 & no & yes & no & no & any "stock" in the treasury \\
\hline 1731 & & $60,000 £^{\mathrm{a}}$ & 0.0 & 20.00 & no & yes & no & no & any "stock" in the treasury \\
\hline 1733 & & $104,000 £^{\mathrm{a}}$ & 0.0 & 20.00 & no & yes & no & no & any "stock" in the treasury \\
\hline 1738 & & $100,000 £^{\mathrm{a}}$ & 0.0 & 20.00 & no & yes & no & no & any "stock" in the treasury \\
\hline 1740 & Dec. 2 & $24,000 £^{\mathrm{a}}$ & 0.0 & 20.00 & yes & yes & no & no & (valued in) specie \\
\hline 1743 & Feb. 14 & $40,000 £^{\mathrm{a}}$ & 0.0 & 20.00 & no & yes & no & no & (valued in) specie \\
\hline 1744 & & $8,750 £$ & 0.0 & ----- & no & yes & no & no & (valued in) specie \\
\hline 1745 & & $8,750 £$ & 0.0 & ----- & no & yes & no & no & (valued in) specie \\
\hline 1746 & & $11,250 £$ & 0.0 & ----- & no & yes & no & no & (valued in) specie \\
\hline 1746 & -7 Feb. 17 & $15,000 £$ & 0.0 & ----- & no & yes & no & no & (valued in) specie \\
\hline 1747 & & $7,500 £$ & 0.0 & ----- & no & yes & no & no & (valued in) specie \\
\hline 1750 & Mar. 18 & $50,000 £^{\mathrm{a}}$ & 0.0 & 20.00 & no & yes & no & no & (valued in) specie \\
\hline \multicolumn{10}{|c|}{ [1751 Currency Act Which Applied only to New England] } \\
\hline 1755 & & $60,000 £$ & 0.0 & 2.00 & no & yes & no & no & (valued in) specie \\
\hline 1756 & Feb. 27 & $8,000 £$ & 0.0 & 1.00 & no & yes & yes & no & lawful money \\
\hline 1756 & Aug. & $6,000 £$ & 0.0 & 2.00 & no & yes & yes & no & lawful money \\
\hline 1758 & May 8 & $10,000 £$ & 5.0 & 5.00 & no & yes & yes & yes & lawful money \\
\hline 1758 & Dec. 23 & $10,909 £$ & 6.0 & 5.00 & no & yes & yes & yes & lawful money \\
\hline 1759 & Mar. 15 & $12,000 £$ & 5.0 & 5.00 & no & yes & yes & yes & lawful money \\
\hline 1759 & Apr. 4 & $4,000 £$ & 5.0 & 5.00 & no & yes & yes & yes & lawful money \\
\hline 1759 & June 23 & $4,000 £$ & 5.0 & 3.00 & no & yes & yes & yes & lawful money \\
\hline 1760 & Mar. 10 & $16,000 £$ & 5.0 & 5.00 & no & yes & yes & yes & lawful money \\
\hline 1760 & May 12 & $11,000 £$ & 5.0 & 5.00 & no & yes & yes & yes & lawful money \\
\hline 1762 & Mar. 20 & $5,000 £$ & 5.0 & 5.00 & no & yes & yes & yes & lawful money \\
\hline 1762 & Apr. 10 & $2,000 £$ & 5.0 & 5.00 & no & yes & yes & yes & lawful money \\
\hline 1762 & May 8 & $2,000 £$ & 5.0 & 5.00 & no & yes & yes & yes & lawful money \\
\hline 1762 & Nov. 1 & $4,000 £$ & 5.0 & 5.00 & no & yes & yes & yes & lawful money \\
\hline 1766 & Mar. 1 & $1,000 £$ & 0.0 & 2.00 & no & yes & yes & no & lawful money \\
\hline 1767 & Feb. 28 & $2,000 £$ & 0.0 & 2.00 & no & yes & yes & no & lawful money \\
\hline \multicolumn{10}{|c|}{ Middle Colonies/States } \\
\hline \multicolumn{10}{|c|}{ New York } \\
\hline 1709 & May 31 & $5,000 £$ & $5.0^{\mathrm{C}}$ & 1.50 & yes & yes & no & no & any "fund" in the treasury \\
\hline 1709 & Nov. 1 & $8,000 £$ & $2.5^{\mathrm{C}}$ & 4.00 & yes & yes & no & yes & any "fund" in the treasury \\
\hline 1711 & July 20 & $10,000 £$ & 0.0 & 7.50 & yes & yes & no & no & any "fund" in the treasury \\
\hline 1714 & July 1 & $27,680 £$ & 0.0 & 21.00 & yes & yes & no & no & any "fund" in the treasury \\
\hline 1715 & July 5 & $6,000 £$ & 0.0 & 5.00 & yes & ---- & ----- & ----- & ----- \\
\hline 1717 & Nov. 28 & $16,607 £$ & 0.0 & 22.00 & yes & yes & no & no & any "fund" in the treasury \\
\hline 1723 & July 2 & $2,140 £$ & 0.0 & 3.00 & yes & yes & no & no & any "fund" in the treasury \\
\hline 1724 & July 10 & $5,670 £$ & 0.0 & 4.00 & yes & yes & no & no & (valued in) current money \\
\hline 1734 & Nov. 15 & $12,000 £$ & 0.0 & 11.67 & yes & yes & no & no & (valued in) current money \\
\hline 1737 & Dec. 10 & $48,350 £^{\mathrm{a}}$ & 0.0 & $12.00^{\mathrm{h}}$ & yes & yes & no & no & (valued in) current money \\
\hline 1746 & May 10 & $13,000 £$ & 0.0 & 2.50 & yes & yes & no & no & (valued in) current money \\
\hline 1746 & July 21 & $40,000 £$ & 0.0 & 10.30 & yes & yes & no & no & (valued in) current money \\
\hline 1747 & Nov. 25 & $28,000 £$ & 0.0 & 8.00 & yes & yes & no & no & (valued in) current money \\
\hline 1755 & Mar. 25 & $45,000 £$ & 0.0 & 5.60 & yes & yes & no & no & (valued in) current money \\
\hline 1755 & May 12 & $10,000 £$ & 0.0 & 6.50 & yes & yes & no & no & (valued in) current money \\
\hline
\end{tabular}




\begin{tabular}{|c|c|c|c|c|c|c|c|c|c|}
\hline 1755 & Sept. 15 & $8,000 £$ & 0.0 & 5.16 & yes & yes & no & no & (valued in) current money \\
\hline 1756 & Feb. 16 & $10,000 £$ & 0.0 & 5.67 & yes & yes & no & no & (valued in) current money \\
\hline 1756 & Apr. 20 & $52,000 £$ & 0.0 & 9.54 & yes & yes & no & no & (valued in) current money \\
\hline 1758 & Apr. 15 & $100,000 £$ & 0.0 & 9.58 & yes & yes & no & no & (valued in) current money \\
\hline 1759 & Apr. 2 & $100,000 £$ & 0.0 & 8.58 & yes & yes & no & no & (valued in) current money \\
\hline 1759 & July 20 & $150,000 £$ & 0.0 & $1.00^{\mathrm{i}}$ & yes & ----- & ---- & ---- & --- \\
\hline 1760 & Apr. 21 & $60,000 £$ & 0.0 & 7.54 & yes & yes & no & no & (valued in) current money \\
\hline \multicolumn{10}{|c|}{ [1764 Currency Act] } \\
\hline 1771 & Feb. 16 & $120,000 £^{\mathrm{a}}$ & 0.0 & 14.00 & no & yes & no & no & (valued in) current money \\
\hline \multicolumn{10}{|c|}{ New Jersey } \\
\hline 1709 & July 1 & $3,000 £$ & $2.5^{\mathrm{C}}$ & 2.00 & yes & yes & no & no & any "fund" in the treasury \\
\hline 1711 & July 14 & $5,000 £$ & 0.0 & 5.00 & yes & yes & no & no & any "fund" in the treasury \\
\hline 1717 & Jan. 24 & $4,670 £$ & 0.0 & 5.00 & yes & yes & no & no & any "fund" in the treasury \\
\hline 1724 & Mar. 25 & $40,000 £^{\mathrm{a}}$ & 0.0 & 12.00 & yes & yes & no & no & any "fund" in the treasury \\
\hline 1733 & Mar. 25 & $20,000 £^{\mathrm{a}}$ & 0.0 & 16.00 & yes & yes & no & no & (valued in) specie \\
\hline 1737 & Mar. 25 & $40,000 £^{\mathrm{a}}$ & 0.0 & 16.00 & yes & yes & no & no & (valued in) specie \\
\hline 1746 & July 2 & $10,000 £$ & 0.0 & ----- g & yes & yes & no & no & (valued in) specie \\
\hline 1755 & May 15 & $15,000 £$ & 0.0 & 4.50 & yes & yes & no & no & (valued in) specie \\
\hline 1755 & Sept. 8 & $15,000 £$ & 0.0 & 5.22 & yes & yes & no & no & (valued in) specie \\
\hline 1756 & Jan. 26 & $10,000 £$ & 0.0 & 5.83 & yes & yes & no & no & (valued in) specie \\
\hline 1756 & June 22 & $17,500 £$ & 0.0 & 6.42 & yes & yes & no & no & (valued in) specie \\
\hline 1757 & Apr. 12 & $10,000 £$ & 0.0 & 6.59 & yes & yes & no & no & (valued in) specie \\
\hline 1757 & June 14 & $5,000 £$ & 0.0 & 6.42 & yes & yes & no & no & (valued in) specie \\
\hline 1757 & Nov. 20 & $30,000 £$ & 0.0 & 16.42 & yes & yes & no & no & (valued in) specie \\
\hline 1758 & May 1 & $50,000 £$ & 0.0 & 20.58 & yes & yes & no & no & (valued in) specie \\
\hline 1758 & Oct. 20 & $10,000 £$ & 0.0 & 2.51 & yes & yes & no & no & (valued in) specie \\
\hline 1759 & Apr. 10 & $50,000 £$ & 0.0 & 8.63 & yes & yes & no & no & (valued in) specie \\
\hline 1760 & Apr. 12 & $45,000 £$ & 0.0 & 13.63 & yes & yes & no & no & (valued in) specie \\
\hline 1761 & Apr. 23 & $25,000 £$ & 0.0 & 17.58 & yes & yes & no & no & (valued in) specie \\
\hline 1762 & Apr. 8 & $30,000 £$ & 0.0 & 18.63 & yes & yes & no & no & (valued in) specie \\
\hline 1763 & Dec. 31 & $10,000 £$ & 0.0 & 18.00 & yes & yes & no & no & (valued in) specie \\
\hline 1764 & Apr. 16 & $25,000 £$ & 0.0 & 19.60 & yes & yes & no & no & (valued in) specie \\
\hline \multicolumn{10}{|c|}{ [1764 Currency Act] } \\
\hline & & 0 & & & & & & & \\
\hline \multicolumn{10}{|c|}{ Pennsylvania } \\
\hline 1723 & Apr. 2 & $15,000 £^{\mathrm{a}}$ & 0.0 & 8.33 & yes & yes & no & no & any "fund" in the treasury \\
\hline 1724 & Jan. 17 & $30,000 £^{\mathrm{a}}$ & 0.0 & 8.08 & yes & yes & no & no & (valued in) current money \\
\hline 1729 & Sept. 15 & $30,000 £^{\mathrm{a}}$ & 0.0 & 16.00 & yes & yes & no & no & (valued in) current money \\
\hline 1731 & Apr. 10 & $85,000 £^{\mathrm{a}}$ & 0.0 & 16.00 & yes & ---- & ----- & ---- & ---- \\
\hline 1739 & Aug. 10 & $80,000 £^{\mathrm{a}}$ & 0.0 & 16.00 & yes & yes & no & no & (valued in) current money \\
\hline 1756 & Jan. 1 & $55,000 £$ & 0.0 & 4.00 & yes & yes & no & no & (valued in) current money \\
\hline 1756 & Oct. 1 & $30,000 £$ & 0.0 & 10.00 & yes & yes & no & no & (valued in) current money \\
\hline 1757 & Mar. 10 & $45,000 £$ & 0.0 & 4.00 & yes & yes & no & no & (valued in) current money \\
\hline 1757 & July 1 & $55,000 £$ & 0.0 & 3.58 & yes & yes & no & no & (valued in) current money \\
\hline 1758 & May 20 & $100,000 £$ & 0.0 & 5.75 & yes & yes & no & no & (valued in) current money \\
\hline 1759 & Apr. 25 & $100,000 £$ & 0.0 & 7.83 & yes & yes & no & no & (valued in) current money \\
\hline 1760 & May 1 & $100,000 £$ & 0.0 & 10.00 & no & yes & no & no & (valued in) current money \\
\hline 1764 & June 18 & $55,000 £$ & 0.0 & 8.25 & yes & yes & no & no & (valued in) current money \\
\hline \multicolumn{10}{|c|}{ [1764 Currency Act] } \\
\hline 1767 & June 15 & $20,000 £$ & 0.0 & 4.00 & no & yes & no & no & (valued in) current money \\
\hline 1769 & Mar. 1 & $16,000 £$ & 0.0 & 4.00 & no & yes & no & no & (valued in) current money \\
\hline 1769 & Mar. 10 & $14,000 £$ & 0.0 & 14.00 & no & yes & no & no & (valued in) current money \\
\hline 1771 & Mar. 20 & $15,000 £$ & 0.0 & 10.00 & no & yes & no & no & (valued in) current money \\
\hline
\end{tabular}




\begin{tabular}{|c|c|c|c|c|c|c|c|c|c|}
\hline 1772 & Apr. 3 & $25,000 £$ & 0.0 & 10.00 & no & yes & no & no & ----- \\
\hline 1773 & Mar. 20 & $12,000 £$ & 0.0 & 15.00 & no & yes & no & no & ----- \\
\hline 1773 & Oct. 1 & $150,000 £^{\mathrm{a}}$ & 0.0 & 16.00 & no & yes & no & no & ---- \\
\hline \multicolumn{10}{|c|}{ Delaware } \\
\hline 1723 & Apr. 23 & $5,000 £^{\mathrm{a}}$ & 0.0 & 8.00 & ----- & ----- & ---- & ---- & ----- \\
\hline 1723 & Nov. 2 & $6,000 £^{\mathrm{a}}$ & 0.0 & 8.00 & ----- & ----- & ----- & ----- & ----- \\
\hline 1729 & & $12,000 £^{\mathrm{a}}$ & 0.0 & 16.00 & ----- & ----- & ----- & ----- & ----- \\
\hline 1734 & Mar. 1 & $12,000 £^{\mathrm{a}}$ & 0.0 & 16.00 & yes & yes & no & no & (valued in) current money \\
\hline 1746 & Feb. 28 & $20,000 £^{\mathrm{a}}$ & 0.0 & 12.00 & ---- & yes & no & no & (valued in) current money \\
\hline 1756 & May 1 & $2,000 £$ & 0.0 & 7.00 & ----- & yes & no & no & (valued in) current money \\
\hline 1758 & Mar. 1 & $4,000 £$ & 0.0 & 7.00 & ----- & yes & no & no & (valued in) current money \\
\hline 1758 & May 1 & $8,000 £$ & 0.0 & 7.00 & ----- & yes & no & no & (valued in) current money \\
\hline 1759 & June 1 & $27,000 £^{\mathrm{a}}$ & 0.0 & 9.00 & yes & yes & no & no & (valued in) current money \\
\hline 1760 & May 31 & $4,000 £$ & 0.0 & 8.00 & ----- & yes & no & no & (valued in) current money \\
\hline \multicolumn{6}{|c|}{ [1764 Currency Act] } & & & & \\
\hline
\end{tabular}

\section{Chesapeake Colonies/States}

\section{Maryland}

1733 Mar. $13 \quad 90,000 £^{\mathrm{a}} \quad 0.0$

1740 June $2 \quad 5,000 £ \quad 0.0$

$31.00^{\mathrm{e}}$ yes yes no no (valued in) current money ---- no yes no no (valued in) current money 1756 July $14 \quad 30,000 £ \quad 0.0 \quad 7.25$ yes yes no no (valued in) current money

[1764 Currency Act of the British Parliament Which Applied to the Non-New England North American Colonies]

\begin{tabular}{|c|c|c|c|c|c|c|c|c|c|}
\hline 1767 & Jan. 1 & $\$ 173,733$ & 0.0 & 11.00 & no & yes & no & no & sterling bills of exchange \\
\hline 1770 & Mar. 1 & $\$ 300,000^{\mathrm{a}}$ & 0.0 & 12.00 & no & yes & no & no & sterling bills of exchange \\
\hline 1774 & Apr. 10 & $\$ 346,667^{\mathrm{a}}$ & 0.0 & 12.00 & no & yes & no & no & sterling bills of exchange \\
\hline \multicolumn{10}{|c|}{ Virginia } \\
\hline 1755 & June & $20,000 £$ & 5.0 & 1.00 & yes & ----- & ----- & ---- & ----- \\
\hline 1755 & Dec. 11 & $40,000 £$ & 5.0 & $4.54^{\mathrm{j}}$ & yes & ----- & ----- & ---- & ----- \\
\hline 1756 & Mar. & $25,000 £$ & 5.0 & $4.25^{\mathrm{j}}$ & yes & ----- & ----- & ---- & ----- \\
\hline 1756 & Mar. & $30,000 £$ & 5.0 & $4.25^{\mathrm{j}}$ & yes & ----- & ----- & ----- & ----- \\
\hline 1756 & Mar. & $10,000 £$ & 0.0 & 1.75 & yes & ----- & ----- & ---- & ----- \\
\hline 1757 & June 8 & $84,963 £$ & 0.0 & $7.75^{\mathrm{jk}}$ & yes & yes & no & no & (valued in) current money \\
\hline 1758 & Apr. 12 & $32,000 £$ & 0.0 & $6.88^{\mathrm{k}}$ & yes & yes & no & no & (valued in) current money \\
\hline 1758 & Oct. 12 & $57,000 £$ & 0.0 & $7.92^{\mathrm{k}}$ & yes & yes & no & no & (valued in) current money \\
\hline 1759 & Apr. 5 & $52,000 £$ & 0.0 & $9.04^{\mathrm{k}}$ & yes & yes & no & no & (valued in) current money \\
\hline 1759 & Nov. 21 & $10,000 £$ & 0.0 & 9.92 & yes & yes & no & no & (valued in) current money \\
\hline 1760 & Mar. 11 & $20,000 £$ & 0.0 & $7.58^{\mathrm{k}}$ & yes & yes & no & no & (valued in) current money \\
\hline 1760 & May 24 & $32,000 £$ & 0.0 & 9.42 & yes & yes & no & no & (valued in) current money \\
\hline 1762 & Apr. 7 & $30,000 £$ & 0.0 & 7.54 & yes & yes & no & no & (valued in) current money \\
\hline \multicolumn{10}{|c|}{ [1764 Currency Act] } \\
\hline 1769 & Nov. 7 & $10,000 £$ & 0.0 & $2.04^{l}$ & no & yes & no & no & (valued in) current money \\
\hline 1771 & July 11 & $30,000 £$ & 0.0 & $4.42^{l}$ & no & yes & no & no & (valued in) current money \\
\hline \multicolumn{10}{|c|}{ Southern Colonies/States } \\
\hline \multicolumn{10}{|c|}{ North Carolina } \\
\hline 1712 & & $4,000 £$ & yes? & ----- & yes & ----- & ----- & ----- & ---- \\
\hline 1713 & & $8,000 £$ & yes? & ----- & yes & ----- & ----- & ----- & ----- \\
\hline 1715 & & $24,000 £$ & 0.0 & ----- & yes & ----- & ----- & ----- & ----- \\
\hline 1722 & Oct. 19 & $12,000 £$ & 0.0 & ----- & yes & yes & no & no & (valued in) current money \\
\hline 1729 & Nov. 27 & $40,000 £^{\mathrm{a}}$ & 0.0 & 15.00 & yes & yes & no & no & (valued in) current money \\
\hline 1735 & Mar. 1 & $12,500 £$ & 0.0 & ----- & no & yes & no & no & lawful money \\
\hline 1748 & Apr. 4 & $21,350 £$ & 0.0 & ----- & yes & yes & no & no & proclamation money \\
\hline
\end{tabular}




\begin{tabular}{|c|c|c|c|c|c|c|c|c|c|}
\hline 1754 & Mar. 9 & $40,000 £$ & 0.0 & ----- & yes & yes & no & no & proclamation money \\
\hline 1756 & Sept. 13 & $3,400 £$ & 6.0 & 1.17 & no & yes & yes & yes & proclamation money \\
\hline 1757 & May 28 & $5,306 £$ & 6.0 & 1.33 & no & yes & yes & yes & proclamation money \\
\hline 1757 & Nov. 21 & $9,500 £$ & 6.0 & 1.00 & no & yes & yes & yes & proclamation money \\
\hline 1758 & May 4 & $7,000 £$ & 6.0 & 1.58 & yes & yes & yes & yes & proclamation money \\
\hline 1758 & Dec. 22 & $4,000 £$ & 6.0 & 2.50 & yes & yes & yes & yes & proclamation money \\
\hline 1760 & July 14 & $12,000 £$ & 0.0 & ----- & yes & yes & no & no & proclamation money \\
\hline 1761 & Apr. 23 & $20,000 £$ & 0.0 & ----- & yes & yes & no & no & proclamation money \\
\hline \multicolumn{10}{|c|}{ [1764 Currency Act] } \\
\hline 1768 & Dec. 5 & $20,000 £$ & 0.0 & 3.50 & no & yes & yes & no & proclamation money \\
\hline 1771 & Dec. & $60,000 £$ & 0.0 & 10.00 & no & yes & no & no & proclamation money \\
\hline \multicolumn{10}{|c|}{ South Carolina } \\
\hline 1703 & May 8 & $6,000 £$ & 12.0 & 3.00 & yes & ----- & ---- & ---- & ---- \\
\hline 1707 & July 5 & $8,000 £$ & 0.0 & 9.00 & yes & ----- & ----- & ----- & ----- \\
\hline 1708 & Feb. 14 & $3,000 £$ & 0.0 & ----- & no & ----- & ----- & ----- & ----- \\
\hline 1708 & Apr. 24 & $5,000 £$ & 0.0 & ----- & no & ----- & ----- & ----- & ----- \\
\hline 1711 & Mar. 1 & $2,000 £$ & 0.0 & ----- & yes & ----- & ---- & ----- & ----- \\
\hline 1711 & Nov.10 & $4,000 £$ & 0.0 & ----- & no & ----- & ----- & ----- & ----- \\
\hline 1712 & June 7 & $36,000 £^{\mathrm{a}}$ & 0.0 & ----- & yes & ----- & ----- & ----- & ---- \\
\hline 1715 & Aug. 27 & $30,000 £$ & 0.0 & ----- & yes & yes & no & no & (valued in) current money \\
\hline 1716 & Mar. 24 & $5,000 £$ & 0.0 & ----- & yes & ----- & ---- & ---- & ---- \\
\hline 1716 & June 30 & $15,000 £$ & 0.0 & ----- & no & ----- & ----- & ----- & ----- \\
\hline 1716 & Aug. 4 & $15,000 £$ & 0.0 & ----- & no & ----- & ----- & ----- & ----- \\
\hline 1719 & Feb. 20 & $15,000 £$ & yes? & ----- & yes & ----- & ----- & ----- & ----- \\
\hline 1720 & June 18 & $19,000 £$ & 0.0 & ----- & yes & ----- & ---- & ----- & ---- \\
\hline 1723 & Feb. 23 & $40,000 £$ & 0.0 & ----- & yes & yes & no & no & (valued in) current money \\
\hline 1731 & Aug. 20 & $104,775 £$ & 5.0 & 6.67 & yes & yes & no & no & (valued in) current money \\
\hline 1737 & Mar. 5 & $35,010 £$ & 0.0 & 5.00 & yes & yes & no & no & (valued in) current money \\
\hline 1740 & Apr. 5 & $25,000 £$ & 0.0 & 4.00 & yes & yes & no & no & (valued in) current money \\
\hline 1740 & Sept. 19 & $11,508 £$ & 0.0 & 4.00 & yes & yes & no & no & (valued in) current money \\
\hline 1757 & July 6 & $229,300 £$ & 0.0 & 5.40 & no & ----- & ----- & ----- & ----- \\
\hline 1760 & July 31 & $316,693 £$ & 0.0 & 5.33 & no & yes & yes & no & (valued in) current money \\
\hline 1760 & Aug. 20 & $125,000 £$ & 0.0 & 6.25 & yes & yes & yes & no & (valued in) current money \\
\hline 1762 & May 29 & $6,000 £$ & 0.0 & ----- & yes & ----- & ----- & ----- & ----- \\
\hline \multicolumn{10}{|c|}{ [1764 Currency Act] } \\
\hline 1767 & Apr. 18 & $60,000 £$ & 0.0 & 5.42 & yes & yes & yes & no & (valued in) current money \\
\hline 1770 & Apr. 7 & $70,000 £$ & 0.0 & 5.00 & no & yes & yes & no & (valued in) current money \\
\hline \multicolumn{10}{|c|}{ Georgia } \\
\hline 1755 & Feb. 17 & $7,000 £^{\mathrm{a}}$ & 0.0 & 7.83 & yes & yes & no & no & (valued in) sterling \\
\hline 1760 & May 1 & $1,100 £$ & 0.0 & 3.42 & yes & yes & yes & no & (valued in) sterling \\
\hline 1762 & Feb. 17 & $3,010 £$ & 0.0 & ----- & yes & yes & no & no & (valued in) sterling \\
\hline 1762 & Mar. 25 & $540 £$ & 0.0 & 5.00 & no & yes & yes & no & (valued in) sterling \\
\hline \multicolumn{10}{|c|}{ [1764 Currency Act] } \\
\hline 1765 & July 8 & $650 £$ & 0.0 & 3.21 & no & yes & yes & no & (valued in) sterling \\
\hline 1766 & Mar. 6 & $1,815 £$ & 0.0 & 5.00 & no & yes & yes & no & (valued in) sterling \\
\hline 1768 & Apr. 11 & $3,375 £$ & 0.0 & 3.08 & no & yes & yes & no & (valued in) current money \\
\hline 1768 & Dec. 24 & $93,046 £$ & 0.0 & 2.33 & no & yes & yes & no & (valued in) current money \\
\hline 1768 & Dec. 24 & $2,200 £$ & 0.0 & 3.33 & no & yes & yes & no & (valued in) sterling \\
\hline 1770 & May 10 & $23,355 £$ & 0.0 & 1.00 & no & yes & yes & no & (valued in) current money \\
\hline 1773 & Sept.29 & $4,299 £$ & 0.0 & 3.00 & no & yes & yes & no & (valued in) current money \\
\hline 1774 & Mar. 12 & $800 £$ & 0.0 & 3.75 & no & yes & yes & no & (valued in) sterling \\
\hline
\end{tabular}

Sources: Information derived and compiled first from Newman (2008); with missing information added from Brock (1975, pp. 26-8, 38-9, 45, 47-9, 66, 72-3, 81-2, 96-9, 108-10, 116-7, 272-5, 300-4, 326-7, 346-7, 386-7, 419, 596); Bullock (1900, pp. 137, 152, 174, 207, 215, 225-6, 232, 238-40); Rodney (1928, pp. 17-36) with corrections made to 
these secondary sources for NY, NJ, PA, MD, and VA from information found in the original sources as reprinted in Archives of Maryland (v. 61, pp. 264-75; v. 62, pp.133-42; v. 64, pp. 242-51); Bush (1977, pp. 63-6, 68-70, 109113, 209-213, 301-19, 427-38, 474-87; 1980, pp. 21-8, 307-19, 345-55, 373-82, 413-25, 455-71, 495-502, 517-29, 539-55, 563-78, 621-39, 663-79; 1982, pp. 73-89, 125-40, 207-21, 289-306); Colonial Laws of New York (v. 1, pp. 654-7, 666-74, 689-97, 730-2, 737-40, 785-8, 815-26, 847-57, 938-47; v. 2, pp. 12-3, 137-48, 173-86, 198-205, 88592, 1015-47; v. 3, pp. 294-5, 381-2, 548-63, 577-93, 660-74, 784-7, 1038-50, 1078-93, 1131-9; v. 4, pp. 43-59, 6076, 156-9, 199-202, 215-35, 301-4, 317-37, 350-5, 385-7, 398-418, 491-4, 554-6, 649-52, 708-10; v. 5, pp. 149-78, 881); Grubb (2015); Hening (1969, v. 6, pp. 435-8, 461-8, 521-30; v. 7, pp. 9-33, 46-54, 69-87, 163-9, 171-231, 255-65, 331-7, 347-53, 465-6, 495-502; v. 8, pp. 342-8, 493-503, 647-52; v. 9, pp. 61-71); Statutes at Large of Pennsylvania (v. 3, pp. 324-8, 389-407; v. 4, pp. 98-116, 197-208, 344-59; v. 7, pp. 100-7, 197-211; v. 8, pp. 15-22, 204-20, 273-300, 417-28, 447-55, 488-90, 495-7).

Notes: Dashed lines indicate that the information was not available in the sources cited. The nominal amount actually emitted could be less than the nominal amount authorized. Only paper monies issued by political legislative bodies are considered. Bills issued explicitly to replace existing bill that were too torn or ragged to continue in circulation or were under threat of being counterfeited or were to merely replace wholesale existing bills are excluded. $£$ refers to the pounds of each colony, respectively, e.g. Pennsylvania pounds for Pennsylvania, New York pounds for New York, and so on. \$ = Spanish silver dollars. Lawful money, also called proclamation money, meant colonial currency valued at the official par of $£ 132.75$ colonial currency per $£ 100.00$ pounds sterling (McCusker 1978, pp. 121, 126, 136, 176). Lawful money was a unit-of-account rating. To receive "lawful money" from a colony's treasury did not mean one received specie. One could still be paid paper money or its equivalent by the treasury. Payments in "lawful money" when rendered in paper money only meant that the paper money was legally rated as equivalent to specie at the proclamation rate set in colonial law. Its value when used as an actual medium of exchange could deviate from this rate. “Current money” meant money as defined by a colony's legal tender acts. It typically referred to a colony’s paper money. The "Issuance-to-Redemption Interval” counts either the years over which these bills could be used to pay the taxes or repay the mortgage-loans of the issuing colony, or how many years into the future before the bills could be exchanged for their face value in specie or sterling bills of exchange, where applicable, by the respective issuing colonial authority. This interval is for the period initially legislated and does not take into account any subsequent postponements or extensions of redemption. "Legal tender" refers to colonial laws that made the notes legal tender for all transactions within the issuing colony, both public and private. Whether an issue was designated a legal tender was taken from the sources cited and from the language printed on the notes. The interest rate reported does not include the interest charged by the colony on bills of credit issued as land-mortgage loans to subjects. In some cases an emission was not listed as a legal tender, but later was forcibly exchanged by law for a new emission that was designated a legal tender. In these cases, the prior emission was listed in the table to be a legal tender.

${ }^{a}$ Some amounts were emitted as loans to subjects who pledged their lands as collateral. The annual interest rate charged by these colonies for these loans and the time-interval of principle repayment ranged from 4 to 10 percent and from 5 to 22 years. A typical loan was at a 5 percent annual interest rate for 12 years.

b The act passed on Dec. 15, 1692 by the Massachusetts assembly gave all Massachusetts bills legal tender status within the colony (Newman 2008, p. 185). It is assumed that this act held for all subsequent emissions by Massachusetts through 1750.

${ }^{\mathrm{C}}$ This was not an interest rate paid directly, but a percentage premium granted when paying taxes using the bills issued. It functioned as a de facto interest rate paid and so is counted as such.

d Taken from the face of the printed bills reproduced in Newman (2008). Dashed lines indicate that no surviving bills were found. Legislated acts often indicated what was to be printed on the bills, but only if surviving bills were found to verify this information was it included in the table.

e One-third was to be redeemed in 15 years and the remaining two-thirds in 31 years. The number reported here is when the last was to be redeemed.

${ }^{\mathrm{f}}$ Maryland invested proceeds from an export tax on tobacco from 1734 to 1765 in Bank of England stock which was then used to support redeeming its bills in London, via sterling bills of exchange .

$\mathrm{g}$ To be redeemed with the specie reimbursement promised by the British Crown for military expenditures, but with no expected redemption/reimbursement date given (Bush 1980, pp. 21-8).

$\mathrm{h}$ The loan portion of this December 1737 emission, 40,000£, had its final redemption date (its principal pay-off date) extended in 1743 to 16.00 years from its initial emission date (effectively April 1738), then extended again in 1750 to 22.00 years from its initial emission date, then extended again in 1756 to 23.00 years from its initial 
emission date, then extended again in 1757 to 24.00 years from its initial emission date, then extended again in 1758 to 25.00 years from its initial emission date, then extended again in 1759 to 26.00 years from its initial emission date, then extended again in 1760 to 27.00 years from its initial emission date, then extended again in 1761 to 28.00 years from its initial emission date, then extended again in 1762 to 29.00 years from its initial emission date, and then extended again in 1763 to 30.00 years from its initial emission date.

i This emission was a one-year loan to His Majesty's forces to be repaid (redeemed) through sterling bills of exchange drawn on His Majesty's paymaster.

${ }^{\mathrm{j}}$ An additional 99,962.5£ of the June 8, 1757 emission were printed and forcibly swapped for the bills of the 1755 and first two 1756 emissions along with their accrued interest on December 1, 1757. The swapped bills would follow the interest payments and redemption dates designated for the June 8, 1757 emission. In effect, this action was an ex post facto removal of interest payments on the 1755 and 1756 bills after December 1, 1757, along with an ex post facto alteration in the redemption or maturity dates of these bills. The payment of accrued interested on the swapped bills to December 1, 1757 added a net gain of 4,962.5£ in bills to the June 8, 1757 emission above the $80,000 £$ in new bills initially authorized.

${ }^{\mathrm{k}}$ In November of 1761 the legislature changed the final redemption dates of these emissions to all being on October 20, 1769. This action extended the Maximum Issuance-to-Final Redemption Interval for the June 8, 1757 emission to 12.38 years, for the April 12, 1758 emission to 11.52 years, for the October 12, 1758 emission to 11.02 years, for the April 5, 1759 emission to 10.54 years, and for the March 11, 1760 emission to 9.60 years.

${ }^{1}$ In March of 1773 the legislature called in all bills from the November 7, 1769 and July 11, 1771 emissions that were still in circulation, amounting to 36,834£, to be swapped for new bills dated March 4, 1773. The swapped amount implies that 68 percent of the November 7, 1769 emission was still outstanding past its initial redemption date. This action was done to thwart the suspected counterfeiting of the 1769 and 1771 bills. The new bills were to be redeemed on June 1, 1774. This action changed the Maximum Issuance-to-Final Redemption Interval for the November 7, 1769 emission to 4.56 years, and for the July 11, 1771 emission to 2.90 years. 


\section{Footnotes}

* Professor of Economics and NBER Research Associate, Economics Department, University of Delaware, Newark, DE 19716, USA. Website: http://www.lerner.udel.edu/facultystaff/faculty/farley-grubb. E-mail: grubbf@udel.edu. Preliminary versions were presented at the Conference on "De-Teleologising History of Money and Its Theory," Japan Society for the Promotion of Science Research-Project 22330102, University of Tokyo, 14-16 February 2012, and the Money, Power, and Print Colloquia, 14-16 June 2012, Halifax, Canada. The author thanks the participants of these conferences and Akinobu Kuroda for helpful comments. Research assistance by James Celia and Lauren Huston, and editorial assistance by Tracy McQueen, are gratefully acknowledged.

${ }^{1}$ Franklin continued with "but the making them a legal Tender in all Payments, and keeping the Quantity within reasonable Bounds.” (Labaree 1970, v. 14, pp. 33-6). However, Franklin, as shown below, argued elsewhere that legal tender laws had no influence on the value of paper money. For this statement here, however, he was under instruction from the Pennsylvania Assembly as its representative to the British government to argue for the necessity of a legal tender law.

${ }^{2}$ Bills of credit were also referred to as Treasury Notes in some colonies, such as in Virginia, see Hening (v. 6, pp. 435-8, 461-8, 521-30; v. 7, pp. 9-33, 46-54, 69-87, 163-9, 171-231, 255-65, 331-7, 347-53, 465-6, 495-502; v. 8, pp. 342-8, 493-503, 647-52; v. 9, pp. 61-71).

${ }^{3}$ Banks successfully emitting paper banknotes backed by fractional specie reserves, with banknotes exchangeable for their face value in specie on demand at the issuing bank, would not appear in English-speaking North America until near the end of the American Revolution (Hammond 1957, pp. 3-64).

${ }^{4}$ See Goldberg (2009); Grubb (2003, 2004, 2010, 2012); Hanson (1979); McCallum (1992); Michener (1987, 1988); Michener and Wright (2005, 2006); Officer (2005); Perkins (1988, pp. 163-86); Rousseau (2006, 2007); Rousseau and Stroup (2011); Smith (1985a, 1985b, 1988); Sumner (1993); West (1978); Wicker (1985). The classical quantity theory of money, at least a prominent version, takes the equation-of-exchange identity, MV = PY, as expressed in growth rates, $\ln (\mathrm{M})+\ln (\mathrm{V})=\ln (\mathrm{P})+\ln (\mathrm{Y})$, and by assuming that $\ln (\mathrm{V})$ and $\ln (\mathrm{Y})$ are long-run constants transforms it into the quantity "theory" of money $[\ln (\mathrm{P})=$ some constant $+\ln (\mathrm{M})]$; where $\mathrm{M}=$ the money supply, $\mathrm{V}=$ the velocity of that money's circulation, $\mathrm{P}=$ prices in that money, and $\mathrm{Y}$ = traded real output (Bordo 1987; Fisher 1912). Economists have typically set $\mathrm{M}$ for each colony equal to the face value quantity of that colony's paper money in circulation.

${ }^{5}$ Even scholars focusing on the fiscal backing of colonial paper money have made such assumptions and ignored such structures. While they claim that colonial paper monies were not fiat currencies but asset monies, they fail to treat these monies as anything other than fiat currencies in their empirical applications. They fail to incorporate rational asset pricing, reconstruct actual redemptions, or incorporate time-discounting. They appear to consider only fiscal backing's effect on risk discounts (RD in equation 1 below). See Smith (1985a, 1985b, 1988); Wicker (1985). On fiat money, see Shubik (1987). 
${ }^{6}$ See fn. 3. For examples, see Benjamin Franklin (Labaree 1967, v. 11, pp. 13-15; 1970, v. 14, pp. 35-8) and James Madison (Hutchinson and Rachal 1962, v. 1, p. 304).

${ }^{7}$ For examples, see the paper money issued by Massachusetts between 1690 and 1738; Connecticut between 1709 and 1734, and in 1740 and 1746; New Hampshire between 1709 and 1741; Rhode Island between 1710 and 1739; New York between 1709 and 1724; New Jersey between 1709 and 1725, and from 1754 through 1763; and Pennsylvania in 1723 (Bush 1977, pp. 63-6, 68-70, 109-3, 209-13; 1980, p. 220; Newman 2008, pp. 90-7, 102, 184-97, 224-31, 248-9, 270-6, 332, 372-81).

${ }^{8}$ This decomposition is consistent with the model of paper money presented by Benjamin Franklin in his treatise written in Philadelphia in 1729 (Labaree 1959, v. 1, p. 153); by Gouverneur Morris in his treatise written in Philadelphia in 1778 (Barlow 2012, pp. 73-6); and by James Madison in his treatise written in 1779 (Hutchinson and Rachal 1962, v. 1, pp. 305-6). As such, it can be considered consistent with how colonial Americans thought about their paper money.

${ }^{9}$ This is how the amount of paper money in circulation is presented in the Historical Statistics of the U.S. (Carter, et al. 2006, pp. 692-6). As such, these data are largely meaningless for most economic analysis purposes.

${ }^{10}$ While a 6 percent discount rate was used in Figure 1 primarily for heuristic purposes, it is the rate Benjamin Franklin and Adam Smith both suggest was likely in use (quoted below). On 17 January 1777, Robert Morris said that 6 percent was the opportunity cost of capital placed in private securities (Smith 1980 6, p. 117). Six percent was also the rate used by the national government for loans between 1776 and 1790, and the most common rate mentioned throughout this period, see Barlow (2012, pp. 110, 125, 128); Catanzariti, et al, (1988 7, p. 547); Elliot (1843); Homer and Sylla (1991, pp. 274-313); Hutchinson and Rachel (1962 1, p. 308); Journals of the Continental Congress (2, pp. 25-26; 6, p. 1037; 7, pp. 102-03, 158, 168; 8, pp. 725-26; 9, pp. 955, 989; 10, p. 59; 11, p. 416; 12, pp. 929-30, 932, 1074, 1256; 13, pp. 112, 141, 146-47, 441, 497; 14, pp. 717, 720, 731-32, 783, 820, 901; 15, pp. 1147, 1197, 1210, 1225, 1245-46, 1288, 1319, 1405; 16, pp. 264-65, 288; 17, pp. 464, 568, 804; 18, p. 1017 19, pp. 6, 167; 21, p. 903; 23, p. 831; 24, p. 39; 26, p. 32; 27, pp. 395-96); Pennsylvania Gazette (30 April; 21 and 28 May; 25 June; 2, 16, and 23 July 1777); Smith (1979 4, p. 295; 1980 6, pp. 117-18, 212-13, 22829, 238-39, 245, 252, 259-62, 270, 277, 295, 346, 368, 372, 386, 400-01, 404; 1981 7, pp. 524, 581, 617, 623, 635, 642-43; 1981 8, p. 25; 1983 10, p. 205; 1985 11, pp. 94, 137-38, 361; 1986 13, pp. 132, 604-05; 1987 14, pp. 51, 463, 500; 1988 15, pp. 377, 396; 1989 16, pp. 307-08, 490, 531; 1990 17, p. 365; 1992 19, p. 139; 1994 21, p. 467). On 6 percent being a common rate in eighteenth-century America, see Brock (1975, pp. 260, 328, 332, 435, 462); Davis (1964 1, p. 326; 2, pp. 38, 68, 83, 99-100, 315, 321; 3, p. 168; 4); Nettels (1934, p. 267).

${ }^{11}$ I have not sorted out the paper money emissions and the APV behavior of paper monies in New England, North and South Carolina, and Georgia. I'm reluctant to rely solely on secondary sources for information on these colonies for this stage of the analysis. 
${ }^{12}$ Derived from the exchange rates quoted in 1703/1704 before bills of credit were issued. In addition, The Boston Evening Post, 25 October 1773, estimated the cost of shipping specie between the colonies and London to be 6 percent. It was comprised of 2.5 percent for insurance and brokerage, 2.5 percent for commissions, and 1 percent for freight (Brock 1992, pp. 74, 124). Adding the opportunity cost of time raises the cost to approximately the rate estimated here. The transaction costs paid by the New Jersey government for moving specie across the Atlantic from 1760 through 1765 was approximately 7.46 percent (Bush 1982, pp. 10-13, 315-16).

${ }^{13}$ The interest payment on Virginia's bills emitted in 1755-6 were removed in 1757 and so are not considered here as affecting these bills' APV.

${ }^{14}$ Scholars, having found it difficult to account for the large swing in the value of Virginia's bills between 1755 and 1770, have resorted to stories about malfeasance, embezzlements, and wartime disruptions to the tobacco market as explanations, see Ernst (1973, pp. 51-88, 174-96); Labaree (1970, v. 14, p. 80).

${ }^{15}$ Adam Smith, in the Wealth of Nations, also noted the absence of annual interest paid by colonial government on their bills of credit (Smith 1937, p. 310). Jeremy Bentham proposed sophisticated interest-bearing paper money regimes (circulating annuities) for England in 1795 and 1800, see Stark (1952 v. 2, pp. 150-300).

${ }^{16}$ See fn. 4.

${ }^{17}$ The colonies lobbied against passage of the 1764 Currency Act and, once passed, worked to repeal it. In the meantime, they hesitated to authorize new paper money without legal tender status, see Appendix Table A1. In the words of Cecilius Calvert (Lord Baltimore, the proprietor of Maryland), the 1764 Currency Act's legal tender prohibition "must a[n]nihilate the valuable consequence of all such Paper Curren[c]y" (Archives of Maryland, v. 14, pp. 141, 170). When Pennsylvania decided in 1767 to attempt a non-legal-tender paper money emission, Benjamin Franklin commented, "I am glad you made a Trial of paper Money without a legal Tender. The Quantity being small, perhaps may be kept up in full Credit notwithstanding...” Labaree (1970, v. 14, p. 231, italics in the original). See also Archives of Maryland, v. 61, pp. c-ci; Ernst (1973, pp. 43-173); Greene and Jellison (1961, pp. 489-93, 503-6); Labaree (1967, v. 11, pp. 175-7; 1968, v. 12, pp. 47-61; 1969, v. 13, pp. 447-9, 465-7; 1970, v. 14, pp. 32-9, 76-88, 180-2, 185, 285-8).

${ }^{18}$ Smith relied on William Douglass, a strident anti-paper-money polemicist from New England, for his information about paper money in America (Bullock 1897, pp. 265-91; Davis 1964, v. 3, pp. 307-63; Smith 1937, p. 310). Smith’s views of colonial paper money may have been colored by this reliance. 